\title{
Review \\ Mixed Metal Oxide by Calcination of Layered Double Hydroxide: Parameters Affecting Specific Surface Area
}

\author{
Su-Bin Lee ${ }^{1}$, Eun-Hye Ko ${ }^{1}$, Joo Y. Park ${ }^{2, * \mathbb{D}}$ and Jae-Min Oh ${ }^{1, *}$ \\ 1 Department of Energy and Materials Engineering, Dongguk University-Seoul, Seoul 04620, Korea; \\ sban0103@naver.com (S.-B.L.); gksmf_2@naver.com (E.-H.K.) \\ 2 Discipline of Information Technology, Media and Communication, Murdoch University, \\ Western Australia 6150, Australia \\ * Correspondence: jooyeon.park@murdoch.edu.au (J.Y.P.); jaemin.oh@donnguk.edu (J.-M.O.); \\ Tel.: +61-8-9360-6257 (J.Y.P.); +82-2-2260-4977 (J.-M.O.)
}

check for updates

Citation: Lee, S.-B.; Ko, E.-H.; Park, J.Y.; Oh, J.-M. Mixed Metal Oxide by Calcination of Layered Double Hydroxide: Parameters Affecting Specific Surface Area. Nanomaterials 2021, 11, 1153. https://doi.org/ 10.3390/nano11051153

Academic Editor: Albert G. Nasibulin

Received: 29 March 2021

Accepted: 27 April 2021

Published: 28 April 2021

Publisher's Note: MDPI stays neutral with regard to jurisdictional claims in published maps and institutional affiliations.

Copyright: (C) 2021 by the authors. Licensee MDPI, Basel, Switzerland. This article is an open access article distributed under the terms and conditions of the Creative Commons Attribution (CC BY) license (https:/ / creativecommons.org/licenses/by/ $4.0 /)$.

\begin{abstract}
Mixed metal oxide (MMO) is one of the widely utilized ceramic materials in various industries. In order to obtain high performance, the specific surface area of MMO should be controlled. Calcination of layered double hydroxide (LDH) is a versatile way to prepare MMO with homogeneous metal distribution and well-developed porosity. Although researchers found that the specific surface area of LDH-originated MMO was relatively high, it had not been systematically investigated how the surface area is controlled under a certain parameter. In this review, we summarized LDH-originated MMO with various starting composition, calcination temperature, and pore developing agent in terms of specific surface area and porosity. Briefly, it was represented that MMOs with $\mathrm{Mg}-\mathrm{Al}$ components generally had higher specific surface area than $\mathrm{Mg}-\mathrm{Fe}$ or $\mathrm{Zn}-\mathrm{Al}$ components. Calcination temperature in the range $300-600{ }^{\circ} \mathrm{C}$ resulted in the high specific surface area, while upper or lower temperature reduced the values. Pore developing agent did not result in dramatic increase in MMO; however, the pore size distribution became narrower in the presence of pore developing agents.
\end{abstract}

Keywords: mixed metal oxide; layered double hydroxide; calcination; specific surface area; metal composition

\section{Introduction}

Mixed metal oxides (MMO) are utilized in various application fields including catalysts, electrodes, adsorbents, etc. In the technical point of view, they can be prepared to have wide variety of composition, crystallinity, particle size, etc. In other word, their electronic structure, surface chemistry, and the degree of unsaturated coordination bonds could be intentionally controlled for the industrially beneficial properties such as adjusted adsorption property and catalytic activity [1-8]. For example, MMOs can be prepared with various metal composition, normally as $\mathrm{Mg}-\mathrm{Al}, \mathrm{Mg}-\mathrm{Fe}, \mathrm{Zn}-\mathrm{Al}$, etc. The MMO composed of $\mathrm{Co}^{2+}$ and $\mathrm{Fe}^{3+}$ was known to be effective in low-temperature $\mathrm{CO}$ oxidation if it had high specific area, modified surface oxygen, and potential metal-metal interaction [9]. Li et al. reported that ternary $\mathrm{MMO}$ having $\mathrm{Cu}-\mathrm{Zn}-\mathrm{Al}$ composition was effective in $\mathrm{H}_{2} \mathrm{~S}$ removal when it had high specific surface area and small crystallite size [10].

Reflecting the above-mentioned importance, diverse synthetic routes have been developed such as ceramic method, sol-gel route, hydrothermal treatment, etc. [11,12]. The ceramic method is the most simple and common way to synthesize metal oxide. This involves precursors such as oxides, carbonates, or metal-salts mixed together and heated at a desired temperature to induce diffusion between two components [13]. In spite of high accessibility and easy preparation, this method has several drawbacks. High energy and temperature are required for reaction and multiple steps are needed for the preparation of complicated composition. Sol-gel route is utilized to produce inorganic polymers or ceramics in stoichiometric manner [14]. The synthesis is proceeded through following steps: 
hydrolysis of precursors to form sol, formation of gel via polycondensation, and aging and drying to form a dense gel. The final product is often dehydrated to obtain intended shape of materials. The MMOs prepared by sol-gel route are known to have high specific surface area with well-developed porosity [15]. Although sol-gel is an economical way to produce a stoichiometric product, it often accompanies shrinkage or crack of product during the drying process, resulting in an unexpected property [16]. Hydrothermal treatment is generally used for substances that are usually insoluble in ordinary temperature and pressure $\left(<100{ }^{\circ} \mathrm{C}, 1 \mathrm{bar}\right)$. Mataji et al. [17] prepared $\mathrm{Zn}-\mathrm{Fe} / \mathrm{Zr}-\mathrm{MMO}$ in a cost-effective manner utilizing hydrothermal method at $180^{\circ} \mathrm{C}$ for $2 \mathrm{~h}$. This method is useful in controlling particle size with high homogeneity; however, its unidentified reaction mechanism hindered minute control of reaction process [18].

Recently, calcination of layered double hydroxide (LDH) has been suggested as an alternative way to prepare MMO. The LDH, also known as anionic clay, is composed of positively charged brucite-like layers and exchangeable anions. Its general chemical formula is described as $\left[\mathrm{M}^{2+}{ }_{1-\mathrm{x}} \mathrm{M}^{3+}{ }_{\mathrm{x}}(\mathrm{OH})_{2}\right]\left(\mathrm{A}^{\mathrm{n}-}\right)_{\mathrm{x} / \mathrm{n}} \cdot \mathrm{mH}_{2} \mathrm{O}$, where $\mathrm{M}^{2+}$ is a divalent metal cation (e.g., $\mathrm{Mg}^{2+}, \mathrm{Zn}^{2+}, \mathrm{Ca}^{2+}$, etc.), $\mathrm{M}^{3+}$ is a trivalent cation (e.g., $\mathrm{Al}^{3+}, \mathrm{Fe}^{3+}, \mathrm{Cr}^{3+}$, etc.), and $\mathrm{A}^{\mathrm{n}-}$ is an exchangeable anion such as $\mathrm{CO}_{3}{ }^{2-}, \mathrm{NO}_{3}{ }^{2-}, \mathrm{SO}_{4}{ }^{2-}$, etc. Due to the variation in metal composition, even ternary or quaternary metal composition is possible [19-24], high anionic exchange capacity, and anisotropic structure, LDHs are widely studied as catalyst, catalytic support, drug delivery carrier, pollutant adsorbent, etc. [25-32]. It is also well-known that $\mathrm{LDH}$, upon calcination, undergoes phase-transformation to MMO through sequential dehydration, dehydroxylation, and gasification of interlayer anions. For example, $\mathrm{Mg}_{6} \mathrm{Al}_{2}(\mathrm{OH})_{16}\left(\mathrm{CO}_{3}\right) \cdot 4 \mathrm{H}_{2} \mathrm{O}$ (hydrotalcite) stoichiometrically alters to $\mathrm{Mg}_{3} \mathrm{AlO}_{4.5}$ (MMO) when they are calcined at an appropriate temperature, between $300^{\circ} \mathrm{C}$ and $600{ }^{\circ} \mathrm{C}$. These MMOs have high thermal stability and relatively large specific surface area [33]. Furthermore, chemical properties of LDH-originated MMO can be controlled by differing the metal components and calcination temperature [34,35]. Thus, the MMOs prepared by this method are widely utilized as catalyst, electrochemical capacitor, antibacterial activity, and adsorbent [36-43].

One of the characteristic features of MMO derived from $\mathrm{LDH}$ is the development of porous structure through gasification process, resulting in relatively high specific surface area. Consequently, LDH-originated MMO have been reported to show high anionic removal capacity $[44,45]$. The phase transformation mechanism from LDH to MMO is not clearly defined yet; however, it is generally accepted that there evolved interstratified $\mathrm{M}(\mathrm{II}) \mathrm{O}$ domains which are connected to each other by $\mathrm{M}$ (III)O tetrahedron. According to the literature survey, we could hypothesize two reasons of porosity in MMO derived from LDH, as illustrated in Scheme 1. First, calcined LDH is used to preserve the morphology of pristine $\mathrm{LDH}$ where several $\mathrm{M}$ (II)O domains are separated with an appropriate distance. The intraparticle space among $\mathrm{M}(\mathrm{II}) \mathrm{O}$ domains would be the first reason of porosity. Second, the calcination process makes $\mathrm{MMO}$ particles form agglomerates, of which the interparticle space provides pores.

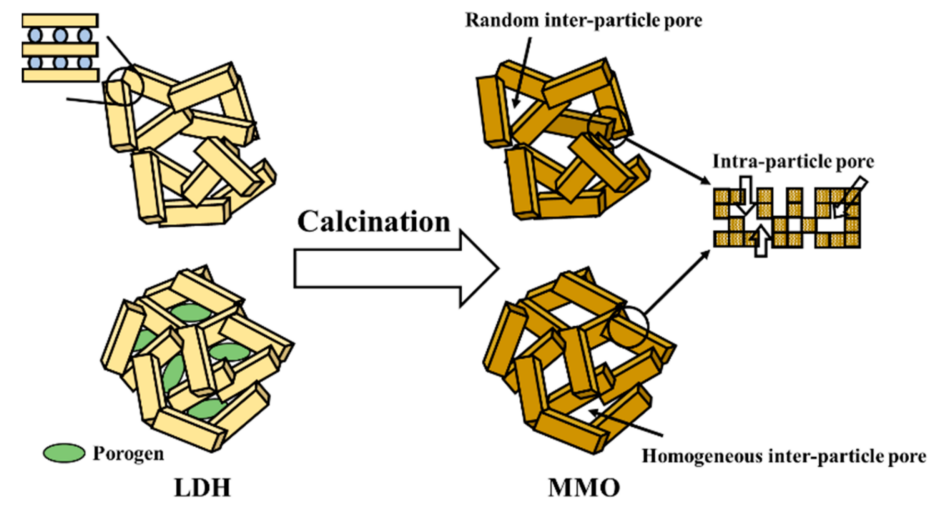

Scheme 1. Intracrystalline structure and porosity of MMO obtained from LDH with and without porogen. 
Although there has been extensive research on the utility of LDH-originated MMO and most of the studies highlighted the importance of specific surface area, to the best of our knowledge, there have not been integrated approaches to comprehend the parameters that affect the specific surface area of MMO. In this contribution, we surveyed the literature on MMOs prepared by LDH to summarize the parameters affecting specific surface area of LDH-based MMO. First of all, the relationship between metal composition of LDH and the specific surface area of $\mathrm{MMO}$ was examined. According to the frequency of report, $\mathrm{Mg}-\mathrm{Al}, \mathrm{Zn}-\mathrm{Al}$, and Mg-Fe composition will be mainly summarized. Then, the effect of calcination temperature parameter on the surface area of MMO was also investigated. In addition, literature on the pore developing template in LDH-originated MMO was also searched. Although the templated method is not an industry friendly method, the pore control by template is important in the technical point of view. By selecting the appropriate metal composition in LDH, controlling calcination temperature, or incorporating poredeveloping template in LDH synthesis, it is possible to control the specific surface area and porosity of MMOs.

\section{Specific Surface Area of MMO Prepared from Calcined LDH}

2.1. Importance of Specific Surface Area Control in Industiral Application of MMO

2.1.1. Market and Industry Trend of MMO

Metal oxide is one of the inorganic materials widely used as catalysts, electrodes, and adsorbents [46], and is used in all fields such as construction and industry, occupying a very important position in the infrastructure industry. MMOs are also used in various range of applications such as semiconductors, ceramics, and medicine as antifungal agents $[47,48]$. In particular, advanced ceramics are being used in various applications such as electronics, transportation, medical, environment, defense and security, and chemical industries, and the global market size is expected to reach $\$ 10,410$ billion by 2021 [49].

In addition, mixed metal oxides have been used in a number of industrially important synthetic conversions used in numerous pharmaceutical and natural products [50]. In the case of the environmental industry, Mochane et al. [11] demonstrated that the use of MMOs spans a wide range of fields, including food packaging, energy, water purification, and gas detection. Environmental ceramics are used in energy and environmental fields through functions such as energy storage, conversion, adsorption, filtration, and decomposition of environmental pollutants [51]. As interest in the global environment increases, demand for ceramic-related materials in the environment sector is expected to increase significantly.

As such, the application of $\mathrm{MMO}$ is remarkably growing with the rapid industrial development of the electronical and electronic, information and communications, and automotive industries. In particular, the ceramic material and parts industry is expected to continue to grow due to the rapid development of the new growth engine industry due to the expansion of the customized high functional material market. However, the ceramic industry is the most competitive in the global market and needs to continuously create new markets through the development of products with new functions [52]. Thus, it is required to expand the government's support for small and medium-sized enterprises, continuous research on MMO-related technologies, and foster professional manpower.

\subsubsection{Importance of Controlling the Specific Surface Area in Industrial Application}

MMO plays a very important role in industrial research and applications as various types of catalysts due to their high surface area and reactive sites [53]. Notably, some of the MMOs are attracting great attention in industrial applications because they play a high catalyst role in numerous reactions by controlling a high specific surface area. This is because as the specific surface area increases, which adsorbs a wide variety of chemicals, the reaction time may be shortened, and the conversion rate of the reactant may increase rapidly [50]. Mixed metal oxide with a high surface area could replace many heterogeneous catalysts, increasing the efficiency of the application. 


\subsection{Controlling the Specific Surface Area of MMO by Calcining Pure LDH}

\subsubsection{Metal Composition of LDH}

\section{- General features}

Among various literature on $\mathrm{LDH}$-originated $\mathrm{MMO}$, the most frequently found composition is Mg-Al. To study metal composition on $\mathrm{S}_{\mathrm{BET}}$ and porosity, we chose two more compositions, $\mathrm{Zn}-\mathrm{Al}$ and $\mathrm{Mg}$-Fe, respectively, in which divalent metal and trivalent metal are replaced by $\mathrm{Zn}$ and $\mathrm{Fe}$, respectively. For statistical analyses, we searched 50, 50, and 20 papers for MgAl-, ZnAl-, and MgFe-MMO, respectively, and summarized them in Table 1.

The effect of metal species on $\mathrm{S}_{\mathrm{BET}}$ was analyzed first and displayed in Figure 1A. The (average value) \pm (standard deviation) of $\mathrm{S}_{\mathrm{BET}}$ was calculated $141.8 \pm 76.6 \mathrm{~m}^{2} / \mathrm{g}$, $81.8 \pm 56.7 \mathrm{~m}^{2} / \mathrm{g}$, and $117.5 \pm 45.9 \mathrm{~m}^{2} / \mathrm{g}$, for MgAl-, $\mathrm{ZnAl}$ - and MgFe-MMO, respectively, suggesting that the specific surface area values were broadly distributed and that there is no statistical difference among composition. However, in-depth analyses suggested that most of the values were located in a certain range: two domains $50-95 \mathrm{~m}^{2} / \mathrm{g}$ and $165-205$ $\mathrm{m}^{2} / \mathrm{g}$ for MgAl-MMO (22 out of 50 examples, dotted box in Figure $\left.1(\mathrm{Aa})\right), 45-85 \mathrm{~m}^{2} / \mathrm{g}$ for ZnAl-MMO (23 out of 50 examples, dotted box in Figure $1(\mathrm{Ab}))$, and $65-110 \mathrm{~m}^{2} / \mathrm{g}$ for $\mathrm{MgFe}-\mathrm{MMO}$ (16 out of 20 examples, dotted box in Figure 1(Ac)). The statistics suggests that metal composition of initial LDH might influence the specific surface area of MMO.

Table 1. Specific surface area values of MMOs depending on metal composition, interlayer anion, and calcination temperature.

\begin{tabular}{|c|c|c|c|c|}
\hline Metal Composition & Interlayer Anion & Temperature $\left({ }^{\circ} \mathrm{C}\right)$ & $\mathrm{S}_{\mathrm{BET}}\left(\mathrm{m}^{2} / \mathrm{g}\right)$ & Ref. \\
\hline \multirow{18}{*}{$\mathrm{MgAl}$} & \multirow{18}{*}{$\mathrm{CO}_{3}{ }^{2-}$} & $450^{\circ} \mathrm{C}$ & $204 \mathrm{~m}^{2} / \mathrm{g}$ & [4] \\
\hline & & $450{ }^{\circ} \mathrm{C}$ & $75-143 \mathrm{~m}^{2} / \mathrm{g}$ & [8] \\
\hline & & $450^{\circ} \mathrm{C}$ & $108-163 \mathrm{~m}^{2} / \mathrm{g}$ & [8] \\
\hline & & $450{ }^{\circ} \mathrm{C}$ & $216-292 \mathrm{~m}^{2} / \mathrm{g}$ & [9] \\
\hline & & $450{ }^{\circ} \mathrm{C}$ & $59 \mathrm{~m}^{2} / \mathrm{g}$ & [12] \\
\hline & & $450{ }^{\circ} \mathrm{C}$ & $209 \mathrm{~m}^{2} / \mathrm{g}$ & [14] \\
\hline & & $450{ }^{\circ} \mathrm{C}$ & $60-133 \mathrm{~m}^{2} / \mathrm{g}$ & [16] \\
\hline & & $450{ }^{\circ} \mathrm{C}$ & $32.9 \mathrm{~m}^{2} / \mathrm{g}$ & [17] \\
\hline & & $500{ }^{\circ} \mathrm{C}$ & $180-210 \mathrm{~m}^{2} / \mathrm{g}$ & [1] \\
\hline & & $500{ }^{\circ} \mathrm{C}$ & $117.6 \mathrm{~m}^{2} / \mathrm{g}$ & [7] \\
\hline & & $500^{\circ} \mathrm{C}$ & $91-250 \mathrm{~m}^{2} / \mathrm{g}$ & [15] \\
\hline & & $700{ }^{\circ} \mathrm{C}$ & $165.1 \mathrm{~m}^{2} / \mathrm{g}$ & [11] \\
\hline & & $750{ }^{\circ} \mathrm{C}$ & $80.4 \mathrm{~m}^{2} / \mathrm{g}$ & [13] \\
\hline & & $300-600^{\circ} \mathrm{C}$ & $210-320 \mathrm{~m}^{2} / \mathrm{g}$ & [2] \\
\hline & & $200-1000{ }^{\circ} \mathrm{C}$ & $55-150 \mathrm{~m}^{2} / \mathrm{g}$ & [3] \\
\hline & & $400-600{ }^{\circ} \mathrm{C}$ & $38-187 \mathrm{~m}^{2} / \mathrm{g}$ & [5] \\
\hline & & $300-700{ }^{\circ} \mathrm{C}$ & $44-58 \mathrm{~m}^{2} / \mathrm{g}$ & [6] \\
\hline & & $200-600^{\circ} \mathrm{C}$ & $80-246 \mathrm{~m}^{2} / \mathrm{g}$ & [10] \\
\hline \multirow{15}{*}{$\mathrm{ZnAl}$} & \multirow{10}{*}{$\mathrm{CO}_{3}^{2-}$} & $370^{\circ} \mathrm{C}$ & $80 \mathrm{~m}^{2} / \mathrm{g}$ & [30] \\
\hline & & $400{ }^{\circ} \mathrm{C}$ & $20-104 \mathrm{~m}^{2} / \mathrm{g}$ & [25] \\
\hline & & $450{ }^{\circ} \mathrm{C}$ & $32.9 \mathrm{~m}^{2} / \mathrm{g}$ & [29] \\
\hline & & $500{ }^{\circ} \mathrm{C}$ & $122 \mathrm{~m}^{2} / \mathrm{g}$ & [23] \\
\hline & & $500{ }^{\circ} \mathrm{C}$ & $129 \mathrm{~m}^{2} / \mathrm{g}$ & [26] \\
\hline & & $500{ }^{\circ} \mathrm{C}$ & $28-86 \mathrm{~m}^{2} / \mathrm{g}$ & [27] \\
\hline & & $500^{\circ} \mathrm{C}$ & $143.3 \mathrm{~m}^{2} / \mathrm{g}$ & [28] \\
\hline & & $500{ }^{\circ} \mathrm{C}$ & $109.5 \mathrm{~m}^{2} / \mathrm{g}$ & [7] \\
\hline & & $300-600{ }^{\circ} \mathrm{C}$ & $51-91 \mathrm{~m}^{2} / \mathrm{g}$ & [24] \\
\hline & & $200-1000{ }^{\circ} \mathrm{C}$ & $6-43 \mathrm{~m}^{2} / \mathrm{g}$ & [18] \\
\hline & \multirow{4}{*}{$\mathrm{NO}_{3}^{-}$} & $750{ }^{\circ} \mathrm{C}$ & $22.5 \mathrm{~m}^{2} / \mathrm{g}$ & [20] \\
\hline & & $150-600{ }^{\circ} \mathrm{C}$ & $29-82 \mathrm{~m}^{2} / \mathrm{g}$ & [31] \\
\hline & & $300-700{ }^{\circ} \mathrm{C}$ & $15-46 \mathrm{~m}^{2} / \mathrm{g}$ & [19] \\
\hline & & $500-700{ }^{\circ} \mathrm{C}$ & $60-71 \mathrm{~m}^{2} / \mathrm{g}$ & [21] \\
\hline & $\mathrm{Cl}^{-}$ & $50-400^{\circ} \mathrm{C}$ & $102-221 \mathrm{~m}^{2} / \mathrm{g}$ & [22] \\
\hline
\end{tabular}


Table 1. Cont

\begin{tabular}{|c|c|c|c|c|}
\hline Metal Composition & Interlayer Anion & Temperature $\left({ }^{\circ} \mathrm{C}\right)$ & $\mathrm{S}_{\mathrm{BET}}\left(\mathrm{m}^{2} / \mathrm{g}\right)$ & Ref. \\
\hline \multirow{18}{*}{$\mathrm{MgFe}$} & \multirow{15}{*}{$\mathrm{CO}_{3}^{2-}$} & $350^{\circ} \mathrm{C}$ & $108-144 \mathrm{~m}^{2} / \mathrm{g}$ & [45] \\
\hline & & $350-550{ }^{\circ} \mathrm{C}$ & $92-96 \mathrm{~m}^{2} / \mathrm{g}$ & [44] \\
\hline & & $400{ }^{\circ} \mathrm{C}$ & $74 \mathrm{~m}^{2} / \mathrm{g}$ & [48] \\
\hline & & $450^{\circ} \mathrm{C}$ & $205 \mathrm{~m}^{2} / \mathrm{g}$ & [46] \\
\hline & & $500{ }^{\circ} \mathrm{C}$ & $168 \mathrm{~m}^{2} / \mathrm{g}$ & [32] \\
\hline & & $500{ }^{\circ} \mathrm{C}$ & $44.3 \mathrm{~m}^{2} / \mathrm{g}$ & [35] \\
\hline & & $500{ }^{\circ} \mathrm{C}$ & $81-127 \mathrm{~m}^{2} / \mathrm{g}$ & [37] \\
\hline & & $500{ }^{\circ} \mathrm{C}$ & $86-128 \mathrm{~m}^{2} / \mathrm{g}$ & [42] \\
\hline & & $600{ }^{\circ} \mathrm{C}$ & $185 \mathrm{~m}^{2} / \mathrm{g}$ & [43] \\
\hline & & $600{ }^{\circ} \mathrm{C}$ & $110 \mathrm{~m}^{2} / \mathrm{g}$ & [47] \\
\hline & & $150-600{ }^{\circ} \mathrm{C}$ & $99-202 \mathrm{~m}^{2} / \mathrm{g}$ & [38] \\
\hline & & $300-500{ }^{\circ} \mathrm{C}$ & $104-196 \mathrm{~m}^{2} / \mathrm{g}$ & [39] \\
\hline & & $400-500{ }^{\circ} \mathrm{C}$ & $116-218 \mathrm{~m}^{2} / \mathrm{g}$ & [40] \\
\hline & & $200-600{ }^{\circ} \mathrm{C}$ & $8-49 \mathrm{~m}^{2} / \mathrm{g}$ & [33] \\
\hline & & $450-550{ }^{\circ} \mathrm{C}$ & $92-112 \mathrm{~m}^{2} / \mathrm{g}$ & [41] \\
\hline & \multirow{2}{*}{$\mathrm{NO}_{3}^{-}$} & $300-700^{\circ} \mathrm{C}$ & $65-86 \mathrm{~m}^{2} / \mathrm{g}$ & [34] \\
\hline & & $500-600{ }^{\circ} \mathrm{C}$ & $78-110 \mathrm{~m}^{2} / \mathrm{g}$ & [36] \\
\hline & $\mathrm{Cl}^{-}$ & $500-600{ }^{\circ} \mathrm{C}$ & $75-110 \mathrm{~m}^{2} / \mathrm{g}$ & [46] \\
\hline
\end{tabular}

(A)

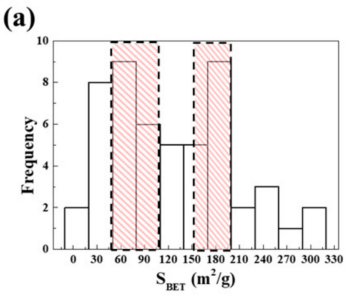

(B)

(b)

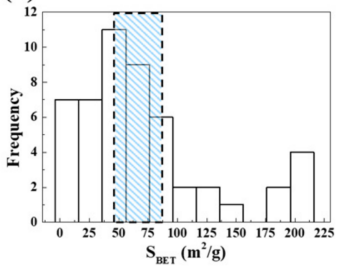

(b)

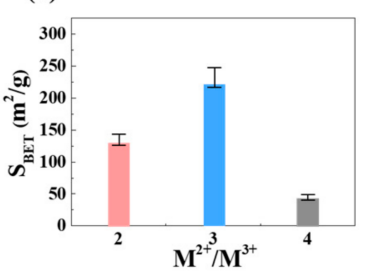

(b)

(C)
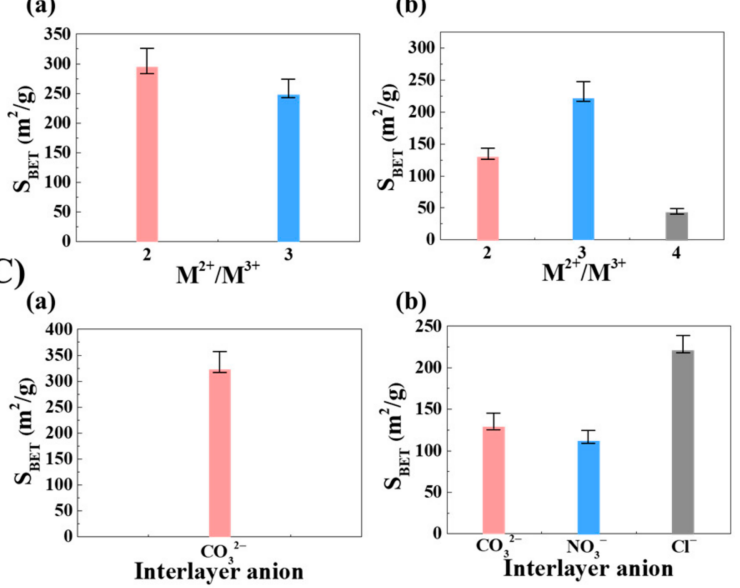

(c)

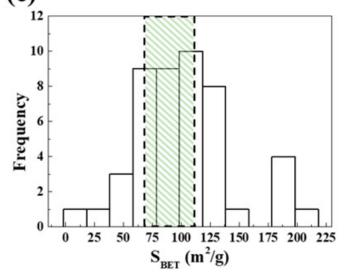

(c)

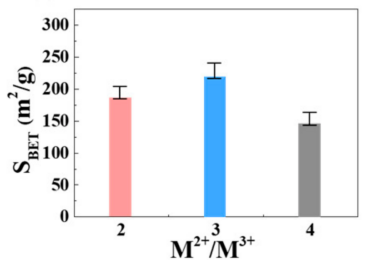

(c)

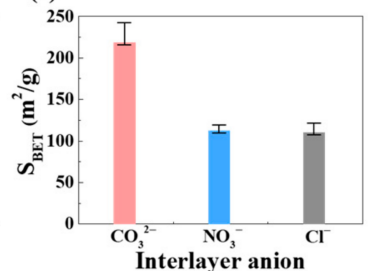

Figure 1. (A) Histogram for the specific surface are values of depending on metal composition. Dotted box stands for the most frequently reported value domain. (B) Average $\mathrm{S}_{\mathrm{BET}}$ and standard deviation of three MMOs depending on metal ratio, (C) Average $S_{\text {BET }}$ and standard deviation of three MMOs depending on interlayer anion. (a) MgAl-MMO, (b) ZnAl-MMO, and (c) MgFe-MMO. The graphs in $(\mathbf{B}, \mathbf{C})$ were prepared with selected values from the literature used in (A).

Metal ratio between divalent and trivalent did not critically affect the $S_{\text {BET }}$ of MMO in $\mathrm{MgAl}$ and $\mathrm{MgFe}$ composition (Figure 1B). However, the $\mathrm{S}_{\mathrm{BET}}$ of $\mathrm{ZnAl}-\mathrm{MMO}$ was fairly dependent on the metal ratio, showing the largest value in 3/1 ratio. It is not clear at this stage how metal ratio affect the specific surface area, it may be related to the role of trivalent ion in $\mathrm{MMO}$, connecting metal oxide domains in interstratified manners. In order 
to fulfill the bridging role, the trivalent ion should be migrated to tetrahedral site from octahedral site. The degree of migration in trivalent ion seems to be dependent on metal ratio in $\mathrm{ZnAl-LDH}$. The 3/1 ratio, which is the most stabilized ratio in hydrotalcite-like structure, seemed to facilitate Al migration to tetrahedral site to support porous structure in MMO.

According to our research, the interlayer anion was also determined to affect specific surface area of MMO. In fact, most of MgAl-MMO were prepared from carbonated-LDH, and thus we could only compare the anionic effect in $\mathrm{ZnAl}$ and $\mathrm{MgFe}-\mathrm{MMO}$. As shown in Figure 1C, ZnAl-MMO showed the largest $\mathrm{S}_{\mathrm{BET}}$ values with chloride-LDH, while MgFeMMO resulted in high $\mathrm{S}_{\mathrm{BET}}$ from carbonated-LDH. It is obvious that nitrated-LDH was not advantageous in producing high specific surface area. When carbonated or chlorideLDHs are calcined in carbon dioxide or hydrochloric acid gas, respectively, it evolves, resulting in pores. However, nitrated-LDH is considered to produce various $\mathrm{NO}_{\mathrm{x}}$ species upon calcination. This unidentified gasification of interlayer anion is attributed to the less development of specific surface area. In addition to the specific surface area, pore size or pore volumes depending on metal composition were also analyzed. As shown in the histogram of Figure 2A, the mean pore diameter of all the MMOs lay in the mesopores region. The MgAl-MMO showed mean pore dimeter values smaller than those of $\mathrm{ZnAl}$ or $\mathrm{MgFe}-\mathrm{MMO}$. The average value of mean pore diameter calculated from the data in Figure 2A were $10.93 \mathrm{~nm} 12.88 \mathrm{~nm}$, and $18.75 \mathrm{~nm}$, respectively, for MgAl, ZnAl, and MgFeMMO. This clearly showed that MgAl-composition is the most favorable in developing small pores. The pore volume analysis also showed advantages in MgAl-composition. As shown in Figure 2B, pore volume tended to be higher in MgAl-MMO. The average pore volume were $0.529 \mathrm{~cm}^{3} / \mathrm{g}, 0.214 \mathrm{~cm}^{3} / \mathrm{g}$, and $0.278 \mathrm{~cm}^{3} / \mathrm{g}$, respectively, for $\mathrm{MgAl}, \mathrm{ZnAl}$, and $\mathrm{MgFe}-\mathrm{MMO}$. This tendency could be explained by not only the different surface energy between $\mathrm{MgO}$ and $\mathrm{ZnO}$ but also the tetrahedral fitting of $\mathrm{Al}^{3+}$ compared with $\mathrm{Fe}^{3+}$. Due to the relatively low surface energy, $\mathrm{MgO}$ tended to preserve smaller crystallite than $\mathrm{ZnO}$; migration of $\mathrm{Al}$ from octahedral to tetrahedral site was more facilitated than that of $\mathrm{Fe}$, resulting in a hierarchically interstratified structure.

(A)

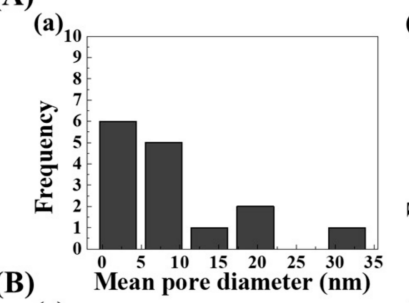

(a)

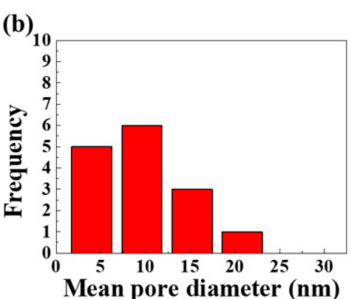

(b)
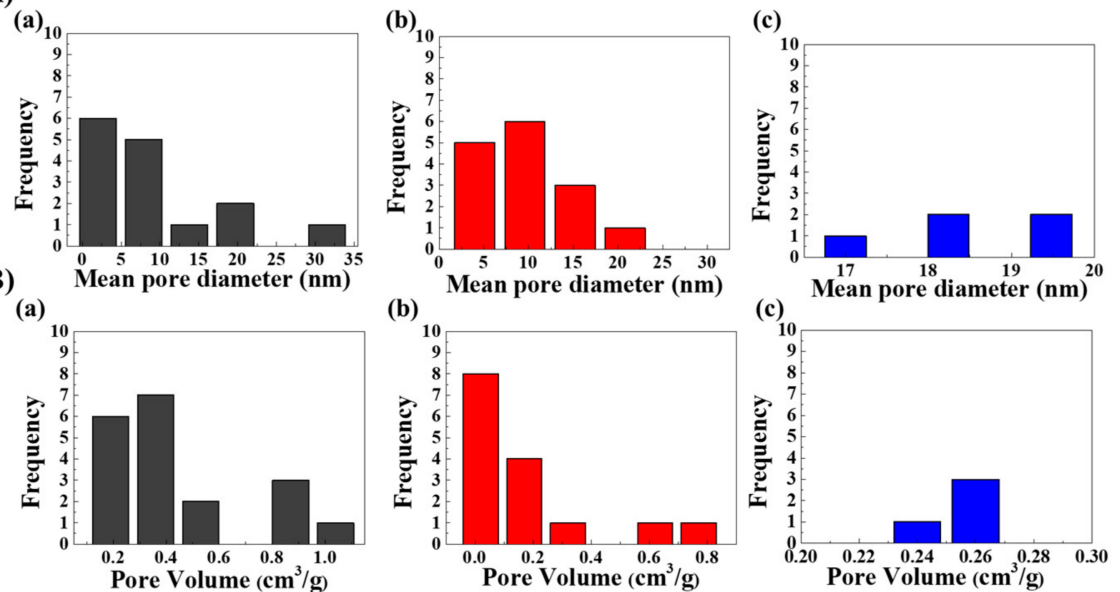

Figure 2. Histograms for the (A) mean pore diameter and (B) pore volume depending on metal composition. (a) MgAl-MMO, (b) ZnAl-MMO, and (c) MgFe-MMO.

Although it cannot be explained by a single rule, the characteristic of initial LDH, synthetic and calcination condition would be related to the property of final MMO. In the successive section, we introduce several examples of MgAl-MMO, ZnAl-MMO and $\mathrm{MgFe}-\mathrm{MMO}$ to suggest specific condition to control specific surface area.

\section{- $\quad$ MgAl-MMO}

$\mathrm{LDH}$ consists of $\mathrm{Mg}$ and $\mathrm{Al}$ is known as mineral hydrotalcite which has general formula of $\mathrm{Mg}_{6} \mathrm{Al}_{2}(\mathrm{OH})_{16}\left(\mathrm{CO}_{3}\right) \cdot 4 \mathrm{H}_{2} \mathrm{O}$. Due to the abundance of $\mathrm{Mg}^{2+}, \mathrm{Al}^{3+}$, and carbonate 
in the earth's crust, hydrotalcite usually occurs in nature; furthermore, it is relatively simple and economic to prepare in a laboratory scale. Thermal treatment of hydrotalcite (MgAl$\mathrm{LDH}$ ) under mild temperature from 300 to $600{ }^{\circ} \mathrm{C}$ results in the formation of small domains of $\mathrm{MgO}$ (periclase, JCPDS No. 14-0191) with connecting Al ${ }^{3+}$ (MgAl-MMO) [54,55]. This phenomenon is one of the major reasons for the development of porosity. Above $600{ }^{\circ} \mathrm{C}$, there evolves thermodynamically stable spinel phase $\left(\mathrm{MgAl}_{2} \mathrm{O}_{4}, \mathrm{JCPDS}\right.$ No. 77-1913), hindering the intended structure of $\mathrm{MMO}$ with high porosity $[56,57]$.

We recently found that the specific surface area values of $\mathrm{MgAl}-\mathrm{MMO}$ were dependent on the synthetic method of pristine LDH [58]. Three kinds of MMOs were prepared from pristine LDHs synthesized by coprecipitation only, hydrothermal treatment after coprecipitation, and urea hydrolysis-based coprecipitation; each MMO was designated as $\mathrm{CMO}, \mathrm{HMO}$, and UMO, respectively. According to SEM measurement (FEI QUANTA 250 FEG, Hillsboro, OR, USA), it was revealed that the three MMOs had comparable particle size with its pristine: $49.45 \pm 12.85 \mathrm{~nm}, 224.86 \pm 18.91 \mathrm{~nm}$, and $1999.68 \pm 255.48 \mathrm{~nm}$ for $\mathrm{CMO}, \mathrm{HMO}$, and UMO, respectively (Figure $3 \mathrm{a}-\mathrm{c}$ ).
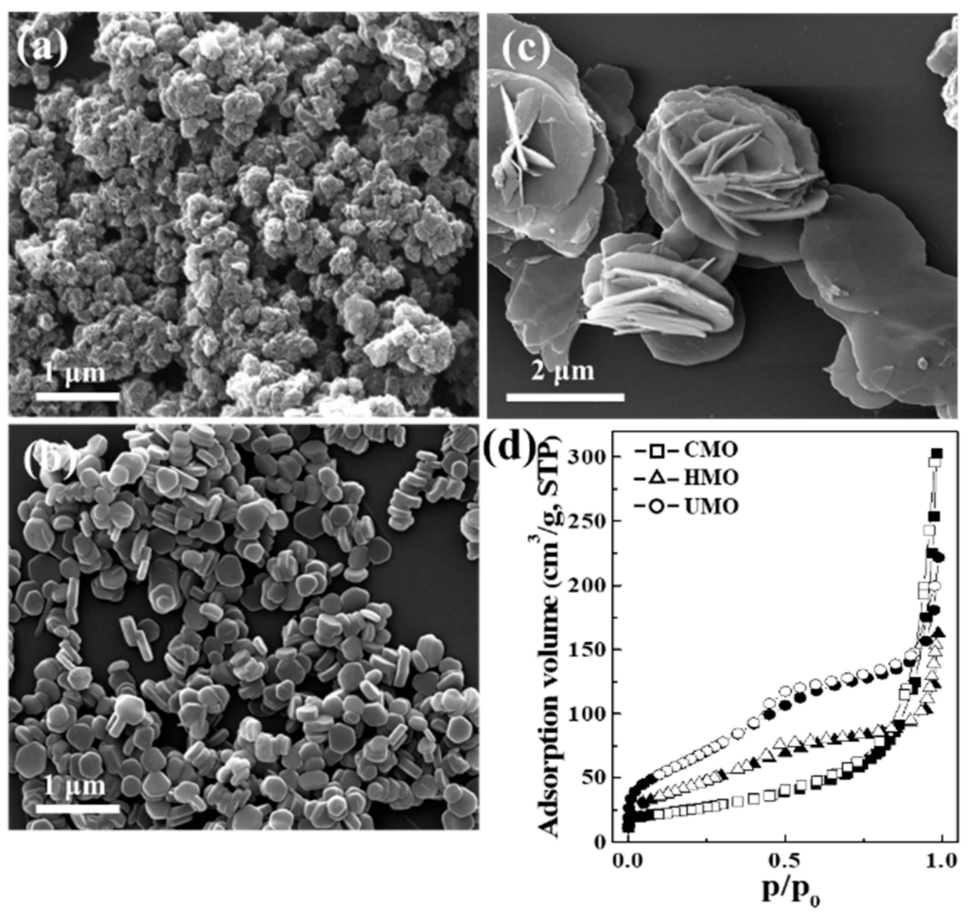

Figure 3. Scanning electron microscopy (SEM) images of (a) $\mathrm{CHO}$, (b) $\mathrm{HMO}$, and (c) UMO. CMO, $\mathrm{HMO}$, and UMO are results of calcination of $\mathrm{LDH}$ that synthesized by coprecipitation, hydrothermal, and urea-hydrolysis, and (d) $\mathrm{N}_{2}$ adsorption-desorption isotherms for CMO, HMO, and UMO (adapted from [58] with the permission from Elsevier, 2020).

Generally, small particle size resulted in more adsorption and larger specific surface area; however, the $\mathrm{S}_{\mathrm{BET}}$ of each $\mathrm{MMO}$ was determined to have reverse relationship: $91.3 \mathrm{~m}^{2} / \mathrm{g}$ for CMO, $168 \mathrm{~m}^{2} / \mathrm{g}$ for $\mathrm{HMO}$, and $250 \mathrm{~m}^{2} / \mathrm{g}$ for UMO (obtained by BELSORPmini II, Microtrac BEL, Inc., Tokyo, Japan). Furthermore, micropore contribution was more clearly shown in larger particle such as UMO. These results clearly suggest that one MMO particle had small $\mathrm{MgO}$ domains and that those domains were more regularly arranged resulting in large intraparticle space and high $S_{\text {BET }}$ (Figure $3 d$ ).

The MgAl-MMO with relatively high specific surface area $\left(>250 \mathrm{~m}^{2} / \mathrm{g}\right)$ could be obtained by applying particular methods in addition to coprecipitation. Yan et al. [59] achieved an $\mathrm{S}_{\mathrm{BET}}$ value of $316 \mathrm{~m}^{2} / \mathrm{g}$ for $\mathrm{MgAl}-\mathrm{MMO}$ by preparing pristine $\mathrm{LDH}$ under water-in-oil microemulsion condition. Aqueous metal cations $\left(\mathrm{Mg}^{2+}\right.$ and $\left.\mathrm{Al}^{3+}\right)$ were titrated with ammonia water inside a microemulsion developed by polyethylene glycol and cyclo- 
hexane. The pristine LDH obtained by this method showed assembly of small and thin particles compared with LDHs prepared by coprecipitation alone (Figure 4a).
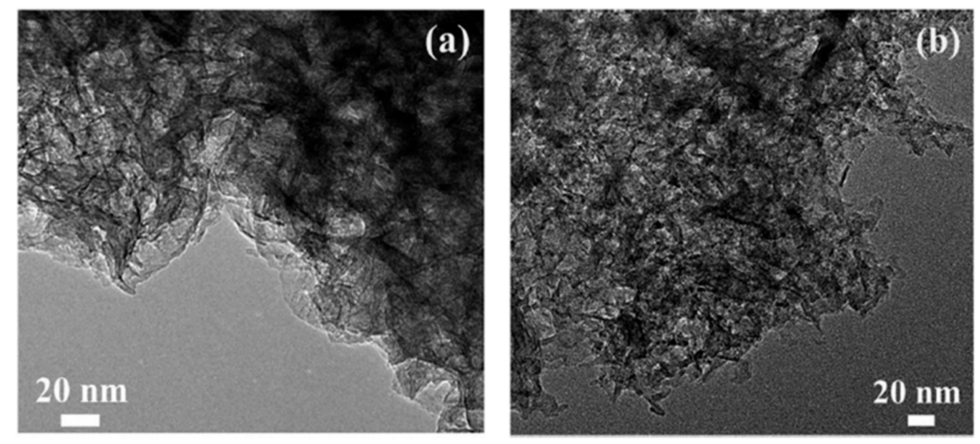

Figure 4. Transmission electron microscopy (TEM, JEM-2100F electron microscope, JEOL Ltd., Tokyo, Japan) images of (a) MgAl-LDH and (b) MgAl-MMO (adapted from [59] with permission with Royal Society of Chemistry, 2016).

After calcination, the building block particles of agglomerates became to have thinner and smaller nanosheets morphology and the nanosheets were interconnected to each other to form porous structure (Figure 4b) [59]. In the introduction, we hypothesized that porosity of MMO is originated from both intraparticle space among $\mathrm{MgO}$ domains and interparticle cavity. Careful prevention of aggregation among particles by microemulsion method seemed to maximize interparticle cavity to enhance $\mathrm{S}_{\mathrm{BET}}$. Another example to obtain high specific surface area in MgAl-MMO is utilizing aqueous miscible organic solvent (AMOS) treatment. This method has been frequently utilized to enhance specific surface area of pristine itself [60]. Zhu et al. [61] prepared LDH through conventional coprecipitation and washed the slurry with acetone (purchased from Sigma-Aldrich Inc., St. Louis, MO, USA). Upon rinsing with acetone, the interlayer water was removed and the interaction between the LDH sheets was weakened, resulting in the exfoliation. During vacuum drying, there occurred reassembly of LDH nanolayers, giving rise to a flower-like structure in which thinner layers were inter-connected (Figure 5).

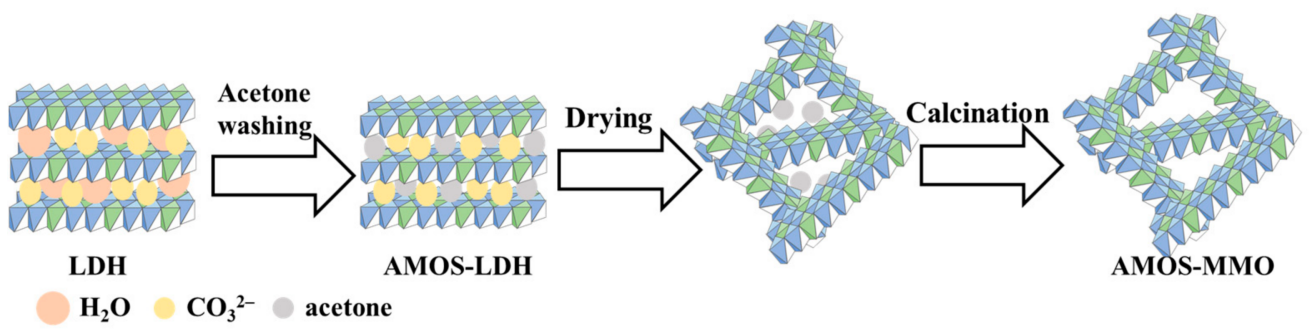

Figure 5. The schematic diagram of synthesis of AMOS-LDH and AMOS-MMO (adapted [61] with permission from Elsevier, 2019).

The AMOS-LDH itself had higher specific surface area value $\left(299 \mathrm{~m}^{2} / \mathrm{g}\right)$ than conventionally prepared $\mathrm{LDH}\left(78 \mathrm{~m}^{2} / \mathrm{g}\right)$. As expected, the AMOS-MMO also had much higher $\mathrm{S}_{\mathrm{BET}}\left(325 \mathrm{~m}^{2} / \mathrm{g}\right)$ than MMO without acetone treatment $\left(256 \mathrm{~m}^{2} / \mathrm{g}\right)$ (obtained by TriStar II Plus, Micromeritics Instruments Corporation, Norcross, GA, USA). The high SET $_{\text {BET }}$ value in this example is also interpreted as the enhancement in interparticle cavity. The hierarchical layer-stacking structure of AMOS-LDH could be robustly maintained during calcination preserving the particle-particle distance, finally maximizing the adsorption site.

- $\quad$ ZnAl-MMO

Similar to MgAl-LDH, thermal treatment on ZnAl-LDH caused the partial collapse in lamellar structure through degassing. Calcination at moderate temperature from $30{ }^{\circ} \mathrm{C}$ to $600{ }^{\circ} \mathrm{C}$ resulted in divalent metal oxide ( $\left.\mathrm{ZnO}\right)$ [62-64]. Different from MgAl-MMO, 
however, the ZnAl-MMO tends to have lower specific surface area (Figure 1(Ab)). The tendency could be interpreted in terms of different chemical nature between $\mathrm{ZnO}$ and $\mathrm{MgO}$. According to the literature, the solid-vapor interface energy was $1.07 \mathrm{~J} / \mathrm{m}^{2}$ and $2.55 \mathrm{~J} / \mathrm{m}^{2}$ for $\mathrm{MgO}$ and $\mathrm{ZnO}$, respectively [65]. This information suggested that the $\mathrm{MgO}$ nanocrystallites can be more stably separated than $\mathrm{ZnO}$, implying aggregation of $\mathrm{ZnO}$ domains. The XRD results from many literatures also showed higher crystallinity of ZnAl$\mathrm{MMO}$ than MgAl-MMO, reflecting the different interface behavior. Based on Gidado et al.'s report [66], we could calculate the crystallinity of both MMOs which were calcined at the same condition. The crystallite size calculated by Scherrer's equation by ourselves was $3.83 \AA$ for ZnAl-MMO (along (100) plane) and $2.88 \AA$ for MgAl-MMO (along (200) plane), strongly suggesting the facilitated crystal growth of $\mathrm{ZnO}$ compared with $\mathrm{MgO}$. According to the hypothesis we suggested in the introduction, the intraparticle space would be smaller in ZnAl-MMO than in MgAl-MMO and the final specific surface area tends to be small in ZnAl-MMO.

As mentioned above, most of the $\mathrm{S}_{\mathrm{BET}}$ values of $\mathrm{ZnAl}-\mathrm{MMO}$ ranged between $45 \mathrm{~m}^{2} / \mathrm{g}$ to $85 \mathrm{~m}^{2} / \mathrm{g}$, exhibiting relatively narrow distribution compared with MgAl-MMO. Huang et al. [67] reported that calcination of hydrothermally prepared ZnAl-LDH resulted in SBET of $32.9 \mathrm{~m}^{2} / \mathrm{g}$, which was a fairly small value. Zhang et al. [68] synthesized ZnAl-LDH through urea hydrolysis method and calcined it and obtained specific surface area values $70.94 \mathrm{~m}^{2} / \mathrm{g}, 62.91 \mathrm{~m}^{2} / \mathrm{g}$, and $60.41 \mathrm{~m}^{2} / \mathrm{g}$ at a calcination temperature of 500,600 , and $700{ }^{\circ} \mathrm{C}$, respectively (obtained by Nova Quantachrome 4000e, Quantachrome Instruments, Boyton Beach, FL, USA). The authors interpreted that the decrease in $S_{\mathrm{BET}}$ with respect to temperature was attributed to the formation of stoichiometric spinel phase with increasing temperature. Starukh and Levytska [69] coprecipitated $\mathrm{ZnAl-LDH}$ in various $\mathrm{Zn} / \mathrm{Al}$ ratio $(2 / 1,3 / 1$, and $4 / 1)$ and calcined them at various temperature from $450{ }^{\circ} \mathrm{C}$ to $600{ }^{\circ} \mathrm{C}$. The $\mathrm{S}_{\mathrm{BET}}$ of their $\mathrm{ZnAl}-\mathrm{MMO}$ distributed between $45 \mathrm{~m}^{2} / \mathrm{g}$ and $94 \mathrm{~m}^{2} / \mathrm{g}$ (obtained by Nova Quantachrome 2200e, Quantachrome Instruments, Boyton Beach, FL, USA), which corresponded to the major distribution range displayed in Figure 1(Ab).

Meanwhile, researchers attempted to obtain high specific surface area in ZnAl-MMO by adopting unique solvents during the synthesis process or introducing interlayer anions other than carbonate. Huang et al. [70] synthesized $\mathrm{ZnAl-LDH}$ under water/n-BuOH mixed solvent condition where the water $/ \mathrm{n}-\mathrm{BuOH}$ ratio was controlled 0.3 and 3 , respectively. As shown in the $\mathrm{N}_{2}$ adsorption-desorption isotherms (ASAP 2460 instruments, Micromeritics Instruments Corporation, Norcross, GA, USA), the ZnAl-LDH prepared under mixed solvent resulted in MMOs with higher nitrogen adsorption (Figure 6).

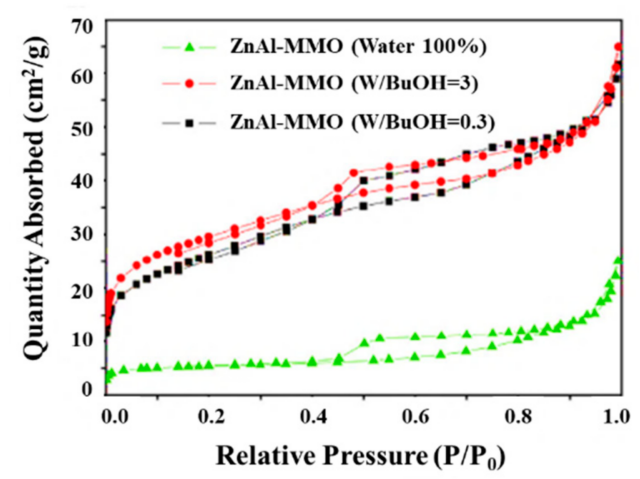

Figure 6. $\mathrm{N}_{2}$ adsorption-desorption isotherms of $\mathrm{ZnAl}-\mathrm{MMO}$ with water, water $/ \mathrm{BuOH}=0.3$ and 3 (adapted from [70] with permission from Elsevier, 2017).

\section{- $\quad \mathrm{MgFe}-\mathrm{MMO}$}

The MgFe-MMO originated from MgFe-LDH was often reported as adsorbents for organic dyes. Different from Al-based MMOs, it is free from Al-related disease such as Alzheimer syndrome [71]. In addition, it is possible to provide iron-based MMOs with mag- 
netic property, which facilitates recovery of adsorbents after scavenging pollutant [72,73]. Similar to the other composition, $\mathrm{MgFe}-\mathrm{LDH}$ undergoes thermal decomposition at $400-600{ }^{\circ} \mathrm{C}$ to produce porous $\mathrm{MMO}$ and transform to mixture of $\mathrm{MgO}$ and $\mathrm{MgFe}_{2} \mathrm{O}_{4}$ spinel phase (JCPDS No. 88-1943) at higher temperature. Therefore, most of the calcination process for $\mathrm{MgFe}-\mathrm{MMO}$ was reported in the temperature range aforementioned.

For instance, Parida et al. [71] prepared MgFe-MMO by using coprecipitated MgFe$\mathrm{LDH}$ as precursor and by calcining it at $500{ }^{\circ} \mathrm{C}$ for $7 \mathrm{~h}$. The specific surface area was $168 \mathrm{~m}^{2} / \mathrm{g}$ (obtained by Qunatasorb-evo, Quantachrome Instruments, Boyton Beach, FL, USA) and exhibited high removal efficiency of selenite from aqueous solution with adsorption capacity $40 \mathrm{mg} / \mathrm{g}$. Similarly, Yu et al. [74] utilized LDH-originated MgFe-MMO to remove aqueous methyl orange (MO) (purchased from Shanghai Chemical Industry Company, Shanghai, China). They precipitated $\mathrm{MgFe}-\mathrm{LDH}$ with different $\mathrm{Mg} / \mathrm{Fe}$ molar ratio, treated precipitates under hydrothermal condition $\left(120^{\circ} \mathrm{C}, 24 \mathrm{~h}\right)$, and calcined LDH at 500 ${ }^{\circ} \mathrm{C}$ for $6 \mathrm{~h}$. Due to the highly crystalline nature of hydrothermally prepared LDH, the $\mathrm{S}_{\mathrm{BET}}$ of prepared MMO lay in the low value range $38.2-48.7 \mathrm{~m}^{2} / \mathrm{g}$ (obtained from Micromeritics ASAP 2020, Micromeritics Instruments Corporation, Norcross, GA, USA). However, due the well-developed pore structure, the material showed fairly high adsorption capacity of $194.9 \mathrm{mg}-\mathrm{MO} / \mathrm{g}-\mathrm{MMO}$. Another example of MgFe-MMO was reported to remove aqueous phosphate (purchased from Fengchuan Chemical Co. Ltd., Tianjin, China) [75]. Coprecipitated $\mathrm{MgFe}-\mathrm{LDH}$ was calcined at different temperature $\left(200-600^{\circ} \mathrm{C}\right)$ for $3 \mathrm{~h}$. The $\mathrm{S}_{\mathrm{BET}}$ of $\mathrm{MMO}$ was the largest at calcination temperature $300^{\circ} \mathrm{C}$ showing $85.6 \mathrm{~m}^{2} / \mathrm{g}$, while the increasing temperature resulted in the decrease of specific surface area.

\subsubsection{Temperature Effect on LDH}

As previously mentioned, the calcination of LDH gradually releases hydroxyls and interlayer anion, accompanying collapse of the layered structure. At moderate calcination temperature, $300-600^{\circ} \mathrm{C}$, the LDH undergoes thermal decomposition to metal oxide. Below $300{ }^{\circ} \mathrm{C}$ the layered structures still remained with relatively low crystallinity. From $300{ }^{\circ} \mathrm{C}$, there appears metal oxide phase due to the dehydroxylation in the framework. Within the increasing in calcination temperature $\left(\sim 600^{\circ} \mathrm{C}\right)$, the characteristic LDH phase finally disappeared, indicating the destruction of the lamellar structure, which was related to the gasification of interlayer anion. Above $600{ }^{\circ} \mathrm{C}$, the generation of spinel phase and disappearance of $\mathrm{MMO}$ phase occurred simultaneously and the spinel phase become more crystalline with increasing temperature, negatively influencing the $S_{\text {BET }}$ value.

Literature research on the $\mathrm{S}_{\mathrm{BET}}$ of $\mathrm{MMO}$ gave us an inspiration that calcination temperature within $300-600{ }^{\circ} \mathrm{C}$ played an important role in controlling the specific surface area. The $\mathrm{S}_{\mathrm{BET}}$ distribution pattern of MgAl-MMO, ZnAl-MMO, and MgFe-MMO with respect to calcination temperature is displayed in Figure 7.

(a)

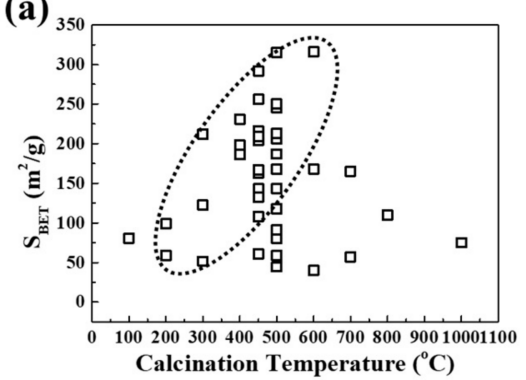

(b)

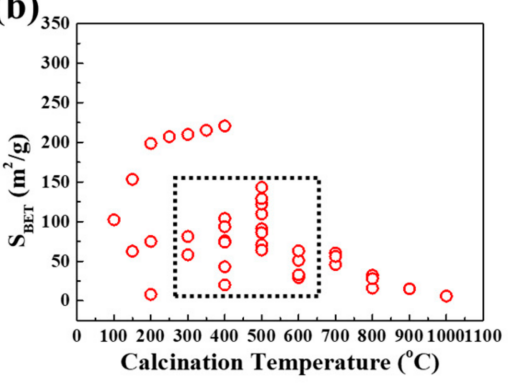

(c)

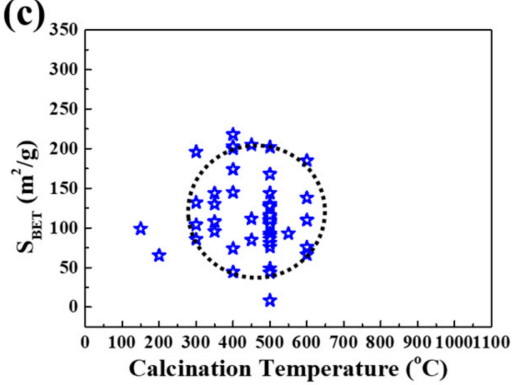

Figure 7. $\mathrm{S}_{\mathrm{BET}}$ distribution patterns by calcination temperature of (a) MgAl-MMO, (b) ZnAl-MMO, and (c) MgFe-MMO. Each dotted region indicates the most frequently observed $S_{B E T}$ values.

The MgAl-MMOs exhibited a wide $S_{\text {BET }}$ distribution from $50 \mathrm{~m}^{2} / \mathrm{g}$ to $325 \mathrm{~m}^{2} / \mathrm{g}$ in the calcination temperatures range between $300-600{ }^{\circ} \mathrm{C}$ (dotted ellipsoid in Figure 7a). The tilted ellipsoid showed increasing $\mathrm{S}_{\mathrm{BET}}$ tendency with respect to calcination temper- 
ature. This pattern was clearly demonstrated in Zhang et al.'s work [76]. They prepared $\mathrm{MgAl}-\mathrm{LDH}$ by conventional coprecipitation method and thermally treated it at various temperatures from $100-600{ }^{\circ} \mathrm{C}$. Calcination temperatures at $100{ }^{\circ} \mathrm{C}$ and $200{ }^{\circ} \mathrm{C}$ resulted in the remaining of LDH phase with low specific surface area, $80.7 \mathrm{~m}^{2} / \mathrm{g}$ and $98.9 \mathrm{~m}^{2} / \mathrm{g}$. From $300-600{ }^{\circ} \mathrm{C}$, the MMO phase was dominant and the $S_{\text {BET }}$ value increased upon temperature: $122.2 \mathrm{~m}^{2} / \mathrm{g}, 198.4 \mathrm{~m}^{2} / \mathrm{g}$, and $245.2 \mathrm{~m}^{2} / \mathrm{g}$ at $300{ }^{\circ} \mathrm{C}, 400{ }^{\circ} \mathrm{C}$, and $500{ }^{\circ} \mathrm{C}$, respectively. Over $600{ }^{\circ} \mathrm{C}$, due to the gradually formed spinel phase, the $S_{B E T}$ decreased to $168.2 \mathrm{~m}^{2} / \mathrm{g}$ (obtained by NOVA 1000e, Quantachrome Instruments, Boyton Beach, FL, USA). The propensity could be addressed by the thermal behavior of MgAl-LDH. As generally depicted in the thermogravimetric and calorimetric analyses (obtained by Shimadzu DT-40, Shimadzu Scientific Instruments, Kyoto, Japan), MgAl-LDH undergoes dehydroxylation and degassing of interlayer anion mainly in the temperature $380-430{ }^{\circ} \mathrm{C}$ (peak maximum); weight loss was continuously observed until $600^{\circ} \mathrm{C}[77,78]$. This stands for that the intraparticle pore (Scheme 1) could be enlarged until $600{ }^{\circ} \mathrm{C}$ with increasing $\mathrm{S}_{\mathrm{BET}}$ value.

Similarly, ZnAl-MMO presented increasing $\mathrm{S}_{\mathrm{BET}}$ up to $500{ }^{\circ} \mathrm{C}$ and decreasing afterward, although most of the $S_{\text {BET }}$ values were observed between $30-150 \mathrm{~m}^{2} / \mathrm{g}$ (dotted rectangle in Figure $7 \mathrm{~b}$ ). The thermogravimetric and calorimetric study (obtained by NETZSCH STA 409 CD, NETZSCH Holding, Selb, Germany; Derivatograph Q-1599 D, MOM, Hungary) showed that the weight loss of ZnAl-LDH continuously occurred until $300{ }^{\circ} \mathrm{C}[79,80]$, suggesting that the increasing intraparticle pore depending on temperature. However, Zhang and Li's study showed the decreasing $S_{\mathrm{BET}}$ value at $600{ }^{\circ} \mathrm{C}$ [81]. This phenomenon could be explained by the high interface energy of $\mathrm{ZnO}$ [65], resulting in particle growth during calcination.

The specific surface area of MgFe-MMO did not show temperature-dependency in the temperature from $300-600{ }^{\circ} \mathrm{C}$, showing most of the $S_{\text {BET }}$ values in the region between $30-150 \mathrm{~m}^{2} / \mathrm{g}$ with fairly independent distribution regardless of temperature (dotted circle in Figure 7c). It is not clear why MgFe-MMO tend to have smaller $\mathrm{S}_{\mathrm{BET}}$; however, one possible explanation is the role of trivalent cation in $\mathrm{MgFe}-\mathrm{MMO}$. It was explained in the introduction that $\mathrm{Al}^{3+}$ in the octahedral site of $\mathrm{LDH}$ partially migrates to tetrahedral site of $\mathrm{MMO}$, which interconnects $\mathrm{M}$ (II)O domains in $\mathrm{MMO}$, producing intraparticle pore. On the other hand, $\mathrm{Fe}^{3+}$ is not appropriate to take the inter-connection role in tetrahedral site due to the following reason. The ionic radius of $\mathrm{Fe}^{3+}, \mathrm{Al}^{3+}$, and $\mathrm{O}^{2-}$ were $70 \mathrm{pm}, 53 \mathrm{pm}$, and $120 \mathrm{pm}$, respectively. Considering the ionic radius ratio $\left(0.42\right.$ for $\mathrm{Fe}^{3+} / \mathrm{O}^{2-}$ and 0.37 for $\left.\mathrm{Al}^{3+} / \mathrm{O}^{2-}\right)$, and $\mathrm{Fe}^{3+}$ was more stable in octahedral interstices than in tetrahedral hole [82]. Due to the size discrepancy, the migration of $\mathrm{Fe}^{3+}$ from octahedral to tetrahedral hole would be restricted, resulting in the less development of porous structure.

\subsection{Effect of Pore Developoing Agent}

The specific surface area of MMO can be finely tuned by utilizing nanometer-sized pore developing agent, porogen, in LDH synthesis. Thermal treatment decomposes porogen in the remaining void space. Size and arrangement of porogen influences dimension and homogeneity of pore in $\mathrm{MMO}$, influencing the specific surface area (Scheme 1). Literature research revealed that the $\mathrm{S}_{\mathrm{BET}}$ value had wide distribution (Figure 8); however, the regularity in porous structure of $\mathrm{LDH}$-originated $\mathrm{MMO}$ was better controlled with the help of porogen. Exact $S_{\mathrm{BET}}$ values depending on the type of porogen was summarized in Table 2 with citation number. 


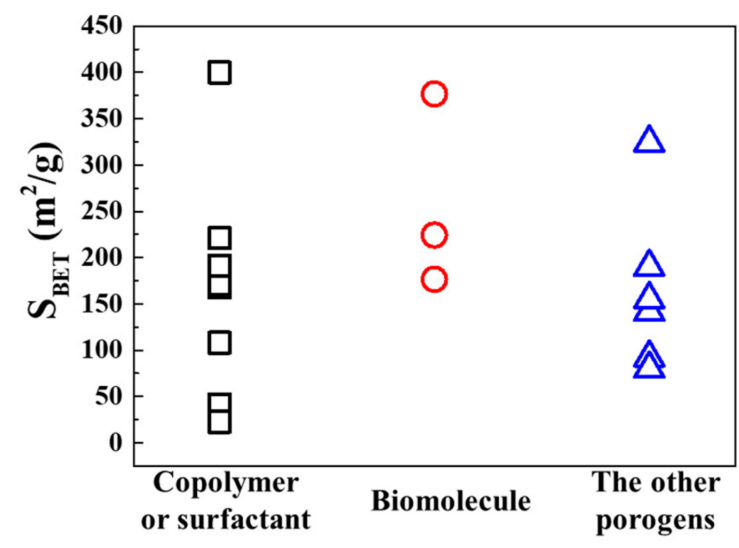

Figure 8. The reported $\mathrm{S}_{\mathrm{BET}}$ value of porous $\mathrm{MMO}$ prepared by the porogen-LDH. Porogen: micelle forming copolymer or surfactants (open square), biomolecules (open circle), the other porogens (open triangle).

- $\quad$ Micelle-Forming Copolymer and Surfactant

One of the most widely utilized porogens is pluronic block copolymer such as F127 and P123, which have been well-demonstrated in the synthesis of mesoporous silica [83-86]. For example, Wang et al. [87] obtained mesoporous MgAl-MMOs utilizing different concentration of P123 solution (purchased from Sigma-Aldrich Inc., St. Louis, MO, USA) during coprecipitation process. Although their maximum $S_{B E T}$ value was not very high $\left(108.1 \mathrm{~m}^{2} / \mathrm{g}\right.$, obtained from Micromeritics ASAP 2010, Micromeritics Instruments Corporation, Norcross, GA, USA), the MMO showed fairly homogeneous nanopores which could be further utilized as reservoir for drug. Similar concept of research was also reported with NiAl-MMO which was prepared from F127 (purchased from Sigma-Aldrich Inc., St. Louis, MO, USA) templated LDH. The paper reported that F127 acted as a template to produce homogenous mesopores with fairly high $S_{\mathrm{BET}}$ of $184 \mathrm{~m}^{2} / \mathrm{g}$ in $\mathrm{MMO}$ and that the homogeneous pore was beneficial in catalytic activity toward Knoevenagel condensation reaction [88]. Kuroda et al. [89] applied F127 (purchased from Sigma-Aldrich Inc., St. Louis, $\mathrm{MO}, \mathrm{USA}$ ) to produce $\mathrm{MMO}$ with high $\mathrm{S}_{\mathrm{BET}}$ and homogeneous pore (obtained by Quantachrome Autosorb $\mathrm{iQ}_{2}$, Quantachrome Instruments, Boyton Beach, FL, USA). Different from the other approaches utilizing pluronic incorporation during coprecipitation, they homogeneously combined monodispersed MgAl-LDH with F127. As a result, they could achieve very high specific surface area of $400 \mathrm{~m}^{2} / \mathrm{g}$. We recently showed that the type of solvent controlled molecular aggregation of pluronic polymer during LDH synthesis, strongly influencing the specific surface area of MMO [90]. In the study, P123-incorporated LDH was coprecipitated on two types of solvent, ethanol and water. It was shown that the P123 aggregated strongly under ethanol condition, while the nanometer-sized micelles were obtained in water system. The specific surface area values of MMOs that were obtained from LDHs synthesized in ethanol and water were $179 \mathrm{~m}^{2} / \mathrm{g}$ and $221 \mathrm{~m}^{2} / \mathrm{g}$, respectively, suggesting that the molecular arrangement of porogen affected the $\mathrm{S}_{\mathrm{BET}}$ of $\mathrm{MMO}$ (obtained by BELSORP-mini II, Microtrac BEL, Inc., Tokyo, Japan). Furthermore, thus obtained MMO with high surface area exhibited dramatically high adsorption capacity of $3470 \mathrm{mg} / \mathrm{g}$ toward Congo Red dye (purchased from Sigma-Aldrich Inc., St. Louis, MO, USA). 
Table 2. Specific surface area values of MMOs depending on the types of porogen.

\begin{tabular}{|c|c|c|c|c|}
\hline & Porogen & Metal Composition & $\mathrm{S}_{\mathrm{BET}}\left(\mathrm{m}^{2} / \mathrm{g}\right)$ & Ref. \\
\hline \multirow{4}{*}{$\begin{array}{l}\text { Micelle forming copolymer } \\
\text { or surfactants }\end{array}$} & P123 & $\mathrm{MgAl}$ & $\begin{array}{c}13-180 \mathrm{~m}^{2} / \mathrm{g} \\
179-221 \mathrm{~m}^{2} / \mathrm{g}\end{array}$ & $\begin{array}{l}{[87]} \\
{[90]}\end{array}$ \\
\hline & F127 & $\begin{array}{l}\mathrm{NiAl} \\
\mathrm{MgAl}\end{array}$ & $\begin{array}{l}97-184 \mathrm{~m}^{2} / \mathrm{g} \\
239-400 \mathrm{~m}^{2} / \mathrm{g}\end{array}$ & $\begin{array}{l}{[88]} \\
{[89]}\end{array}$ \\
\hline & Dioctyl sulfosuccinate & $\mathrm{Mg}$ & $41-192 \mathrm{~m}^{2} / \mathrm{g}$ & [91] \\
\hline & cetyltrimethylammonium bromide & $\mathrm{ZnAl}$ & $9-31 \mathrm{~m}^{2} / \mathrm{g}$ & [92] \\
\hline \multirow{3}{*}{ Biomolecule } & Albumin & $\mathrm{MgAl}$ & $176-225 \mathrm{~m}^{2} / \mathrm{g}$ & [48] \\
\hline & Sodium Alginate & $\mathrm{MgAl}$ & $123-377 \mathrm{~m}^{2} / \mathrm{g}$ & [93] \\
\hline & Rape pollen & $\mathrm{ZnAlCe}$ & $97-113 \mathrm{~m}^{2} / \mathrm{g}$ & [94] \\
\hline \multirow[b]{2}{*}{ The others } & MOF & $\mathrm{CoNi}$ & $64-127 \mathrm{~m}^{2} / \mathrm{g}$ & [95] \\
\hline & Glucose & $\begin{array}{l}\mathrm{NiAl} \\
\mathrm{MgAl}\end{array}$ & $\begin{array}{l}144-288 \mathrm{~m}^{2} / \mathrm{g} \\
151-323 \mathrm{~m}^{2} / \mathrm{g}\end{array}$ & $\begin{array}{l}{[96]} \\
{[97]}\end{array}$ \\
\hline
\end{tabular}

Meanwhile, researchers also reported that micelle-forming molecular surfactant could be utilized as porogen for MMO production. He et al. selected dioctyl sulfosuccinate sodium (purchased from Sigma-Aldrich Inc., St. Louis, MO, USA). as a porogen for MgAl-MMO [91]. As the concentration of surfactant increased, the specific surface area of MMO increased from $41.43 \mathrm{~m}^{2} / \mathrm{g}$ to $191.36 \mathrm{~m}^{2} / \mathrm{g}$ (obtained from Micromeritics Rise 1030, Micromeritics Instruments Corporation, Norcross, GA, USA), which was much higher than the $S_{\text {BET }}$ of MMO obtained without porogen $\left(15.35 \mathrm{~m}^{2} / \mathrm{g}\right)$. Another research reported that cationic surfactant, cetyltrimethylammonium bromide, can be utilized to prepare mesoporous ZnAl-MMO [92]. Although the $S_{\mathrm{BET}}\left(22.57 \mathrm{~m}^{2} / \mathrm{g}\right)$ of the prepared $\mathrm{ZnAl}$ MMO was not high (obtained from Micromeritics ASAP 2020, Micromeritics Instruments Corporation, Norcross, GA, USA), they suggested the potential utility of micelle-forming surfactant in the preparation of homogenous mesopores in MMO.

- Biomolecules

The above-mentioned porogen facilitated formation of self-assembled micelles, resulting in the development of pores after removal. Similar strategy is possible with intrinsically nano-sized biomolecules. We recently found that calcination of albumin-templated LDH produced MgAl-MMO with fairly high specific surface area. In this study, albumin (purchased from Sigma-Aldrich Inc., St. Louis, MO, USA) was added during two different $\mathrm{LDH}$ synthesis routes, coprecipitation and reconstruction, respectively (Figure 9a) [48].

The MMO obtained from reconstructed albumin-LDH had higher $S_{\text {BET }}\left(224.3 \mathrm{~g} / \mathrm{m}^{2}\right)$ than $\mathrm{MMO}$ from coprecipitated albumin-LDH $\left(\mathrm{S}_{\mathrm{BET}}=176.6 \mathrm{~m}^{2} / \mathrm{g}\right)$. This was attributed to the different degree of aggregation of albumin depending on synthetic condition; reconstruction reaction preserves constant $\mathrm{pH}$ value, resulting in the homogeneous distribution of albumin as porogen. Thus, the reconstructed MMO contained well-developed interparticle pore (Figure $9 \mathrm{~b}$ ) in addition to intra-particle pore resulting in narrow pore size distribution (Figure 9c). Xu et al. [93] utilized sodium alginate (purchased from Sinopharm Chemical Reagent Co., Ltd., Shanghai, China) as a porogen for MgAl-MMO. They coprecipitated MgAl-LDH in the presence of sodium alginate solution. The alginate-templated LDH resulted in MMO with fairly high $\mathrm{S}_{\mathrm{BET}}$ of $376.8 \mathrm{~m}^{2} / \mathrm{g}$. Biological organism with hierarchical structure such as rape pollen was also be utilized as porogen. Duan et al. [94] precipitated $\mathrm{ZnAlCe}-\mathrm{LDH}$ in the presence of rape pollen and calcined it at $550{ }^{\circ} \mathrm{C}$. The MMO was obtained in a large particle morphology with hierarchically connected pores. They showed that the porous MMO had excellent activity as heterogenous catalysis. 
(a)

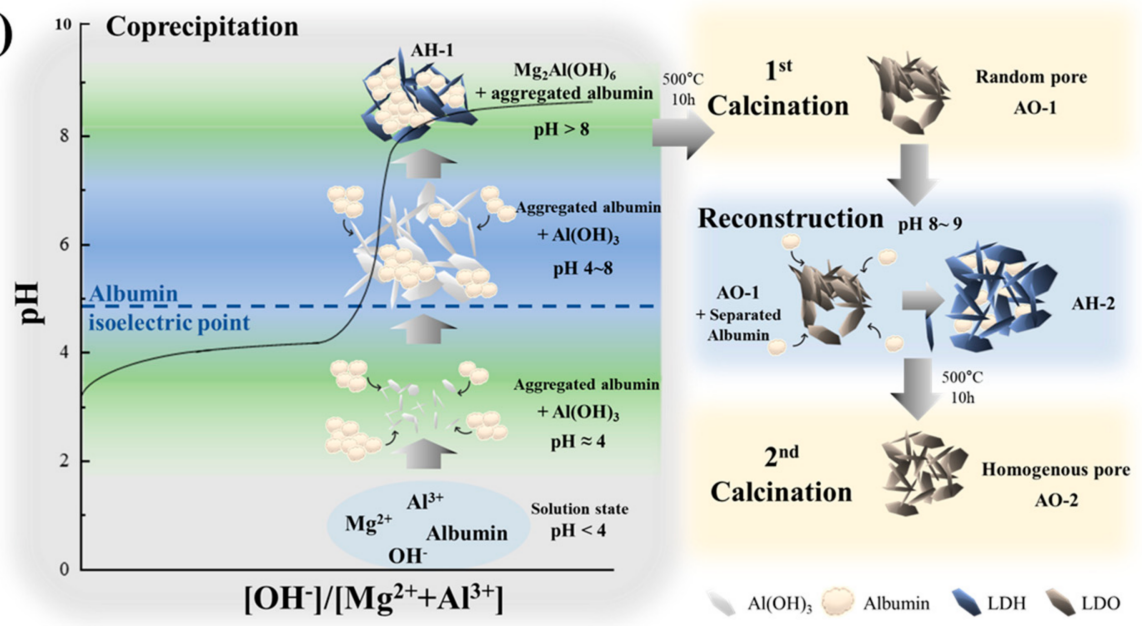

(b)

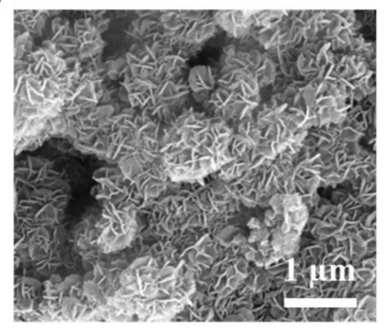

(c)

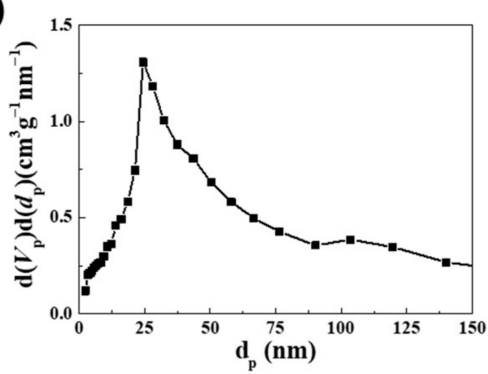

Figure 9. (a) Schematic diagram to produce MMOs from either coprecipitated albumin-LDH or reconstructed albumin-LDH. (b) SEM image (obtained by FEI QUANTA 250 FEG, Hillsboro, OR, USA) and (c) pore size distribution of MMO obtained from reconstructed albumin-LDH (obtained by BELSORP-mini II, Microtrac BEL, Inc., Japan) (adapted with the permission from Jung et al. [48]. Copyright MDPI).

\section{- $\quad$ The other porogens}

Self-templating synthesis of MMO could be an alternative method to evolve mesopores and enhance specific surface area of MMO. Chen et al. [95]. transformed ZIF-67 to metal-organic frameworks into 3D hollow structure of $\mathrm{LDH}$. Upon successive etching and calcination, they could obtain hierarchical nanocage of $\mathrm{NiCO}_{2} \mathrm{O}_{4} / \mathrm{NiO}$ composition. The MMO showed moderate $S_{\text {BET }}$ value of $141.6 \mathrm{~m}^{2} / \mathrm{g}$ (obtained by AS-1-C TCD, Quantachrome Instruments, Boyton Beach, FL, USA) and excellent catalytic activity.

Glucose template was another approach to generate mesoporous MMO. Li et al. [96] proposed NiAl-LDH/carbon composite as a precursor for porous MMO. First, LDH was prepared with glucose, and then hydrothermally treated at $150{ }^{\circ} \mathrm{C}$, at which condition the glucose underwent carbonization. The removal of carbon by calcination resulted in MMO with high specific surface area and interconnected mesopores (obtained by Quantachrome Autosorb-1C-VP, Quantachrome Instruments, Boyton Beach, FL, USA). Similarly, Feng et al. [97]. developed spinel type $\mathrm{MgAl}-\mathrm{MMO}$ by coprecipitation and hydrothermal process in the presence of glucose. The $\mathrm{MgAl}_{2} \mathrm{O}_{4}$ spinel exhibited high specific surface area of $324 \mathrm{~m}^{2} / \mathrm{g}$. The organic glucose contributed to the evolution of mesopores and high specific surface area (obtained by Micromeritics TriStar 3000, Micromeritics Instruments Corporation, Norcross, GA, USA).

\section{Conclusions}

Application and utility of MMO is increasing in various fields such as catalysts, electrodes, adsorbents, construction, environment, etc. due to their diverse composition and high specific surface area. One of the recent approaches to prepare MMO is calcining 
$\mathrm{LDH}$; thermal treatment on $\mathrm{LDH}$ gives rise to dehydration, simultaneous dehydroxylation, and degassing of anion, and development of the spinel phase depending on temperature. According to the literature survey, calcination at moderate temperature $300-600{ }^{\circ} \mathrm{C}$ resulted in pure $\mathrm{MMO}$ with fairly high specific surface area. Calcination at lower or higher temperature resulted in the mixture of (hydrotalcite $+\mathrm{MMO}$ ) or (spinel + MMO) to decrease the specific surface area. It is expected that there are two reasons of $\mathrm{S}_{\mathrm{BET}}$ increase at moderate temperature: (i) formation of intraparticle pore coming from the degassing and (ii) interparticle space which is strongly governed by the interaction of particles.

As for the metal composition effect on $\mathrm{S}_{\mathrm{BET}}, \mathrm{MgAl}-\mathrm{MMO}$ generally tended to show relatively large specific surface than ZnAl-MMO (45-85 m²/g), while MgFe-MMO had wide range of $\mathrm{S}_{\mathrm{BET}}$. This may be highly related to the surface energy of divalent metal oxide $(\mathrm{MgO}$ or $\mathrm{ZnO})$ and site preference of $\mathrm{Al}^{3+}$ and $\mathrm{Fe}^{3+}$. In order to achieve very high $\mathrm{S}_{\mathrm{BET}}$, specific synthetic process such as AMOST, water-n-BuOH solvent, water-inoil microemulsion method were applied; in this way, thinner and small pristine LDH particles could be prepare and the inter-particle space would be well-preserved to enhance high specific surface area. Calcination temperature was determined to be related with specific surface area, showing generally increasing $\mathrm{S}_{\mathrm{BET}}$ upon temperature. In addition, the utility of pore-developing agent was also adapted in LDH-originated MMO. Although the $S_{\text {BET }}$ value did not dramatically increase in the presence of porogen, it could develop homogeneous porous structure, which is advantageous in adsorbent or catalyst.

Author Contributions: J.-M.O., conceptualization, resources, writing-review and editing, supervision, funding acquisition, project administration; J.Y.P., supervision, writing-review and editing; S.-B.L., investigation, writing-original draft preparation, visualization, validation; E.-H.K., investigation. All authors have read and agreed to the published version of the manuscript.

Funding: This research was funded by the Dongguk University Research Fund of 2019 and Murdoch university Research Fund of 2019.

Institutional Review Board Statement: Not applicable.

Informed Consent Statement: Not applicable.

Data Availability Statement: No new data were created or analyzed in this study. Data sharing is not applicable to this article.

Conflicts of Interest: The authors declare no conflict of interest.

\section{References}

1. Wachs, I.E. Recent conceptual advances in the catalysis science of mixed metal oxide catalytic materials. Catal. Today 2005, 100, 79-94. [CrossRef]

2. Fan, G.; Sun, W.; Wang, H.; Li, F. Visible-light-induced heterostructured Zn-Al-In mixed metal oxide nanocomposite photocatalysts derived from a single precursor. Chem. Eng. J. 2011, 174, 467-474. [CrossRef]

3. Pan, D.; Ge, S.; Zhao, J.; Shao, Q.; Guo, L.; Zhang, X.; Lin, J.; Xu, G.; Guo, Z. Synthesis, characterization and photocatalytic activity of mixed-metal oxides derived from NiCoFe ternary layered double hydroxides. Dalton Trans. 2018, 47, 9765-9778. [CrossRef] [PubMed]

4. Kadam, S.L.; Mane, S.M.; Tirmali, P.M.; Kulkarni, S.B. Electrochemical synthesis of flower like Mn-Co mixed metal oxides as electrode material for supercapacitor application. Curr. Appl. Phys. 2018, 18, 397-404. [CrossRef]

5. Kitiyanan, A.; Ngamsinlapasathian, S.; Pavasupree, S.; Yoshikawa, S. The preparation and characterization of nanostructured $\mathrm{TiO}_{2}-\mathrm{ZrO}_{2}$ mixed oxide electrode for efficient dye-sensitized solar cells. J. Solid State Chem. 2005, 178, 1044-1048. [CrossRef]

6. Hu, C.; Wang, T.; Dong, J.; Liu, R.; Liu, H.; Qu, J. Capacitive deionization from reconstruction of NiCoAl-mixed metal oxide film electrode based on the "memory effect". Appl. Surf. Sci. 2018, 459, 767-773. [CrossRef]

7. Romano, E.J.; Schulz, K.H. A XPS investigation of $\mathrm{SO}_{2}$ adsorption on ceria-zirconia mixed-metal oxides. Appl. Surf. Sci. 2005, 246, 262-270. [CrossRef]

8. Gao, Y.; Zhang, Z.; Wu, J.; Yi, X.; Zheng, A.; Umar, A.; O'Hare, D.; Wang, Q. Comprehensive investigation of $\mathrm{CO}_{2}$ adsorption on $\mathrm{Mg}-\mathrm{Al}-\mathrm{CO}_{3} \mathrm{LDH}-$ derived mixed metal oxides. J. Mater. Chem. A 2013, 1, 12782-12790. [CrossRef]

9. Biabani-Ravandi, A.; Rezaei, M.; Fattah, Z. Study of Fe-Co mixed metal oxide nanoparticles in the catalytic low-temperature CO oxidation. Process Saf. Environ. Prot. 2013, 91, 489-494. [CrossRef]

10. Yang, Y. Recent advances in the electrochemical oxidation water treatment: Spotlight on byproduct control. Front. Environ. Sci. Eng. 2020, 14, 1-12. [CrossRef] 
11. Kapoor, P.N.; Bhagi, A.K.; Mulukutla, R.S.; Klabunde, K.J. Mixed metal oxide nanoparticles. Dekker Encycl. Nanosci. Nanotechnol. 2004, 2007-2015. [CrossRef]

12. Cousin, P.; Ross, R.A. Preparation of mixed oxides: A review. Mater. Sci. Eng. A 1990, 130, 119-125. [CrossRef]

13. Rao, C.N.R.; Biswas, K. Essentials of Inorganic Materials Synthesis; John Wiley \& Sons: Hoboken, NJ, USA, 2015.

14. Ogoshi, T.; Chujo, Y. Organic-inorganic polymer hybrids prepared by the sol-gel method. Compos. Interfaces 2005, 11, 539-566. [CrossRef]

15. Hernández, A.; Maya, L.; Sánchez-Mora, E.; Sánchez, E.M. Sol-gel synthesis, characterization and photocatalytic activity of mixed oxide $\mathrm{ZnO}-\mathrm{Fe}_{2} \mathrm{O}_{3}$. J. Sol-Gel Sci. Technol. 2007, 42, 71-78. [CrossRef]

16. Carter, C.B.; Norton, M.G. Sols, gels, and organic chemistry. In Ceramic Materials; Springer: Berlin/Heidelberg, Germany, 2013; pp. $411-422$.

17. Mataji, M.; Ghorbani, M.; Gatabi, M.P. Structural, optical and magnetic properties of novel $\mathrm{ZnFe}_{2} \mathrm{O}_{4} / \mathrm{ZrO}_{2}$ mixed metal oxide nanocomposite synthesized by hydrothermal technique. J. Alloys Compd. 2018, 757, 298-309. [CrossRef]

18. Shandilya, M.; Rai, R.; Singh, J. Review: Hydrothermal technology for smart materials. Adv. Appl. Ceram. 2016, 115, 354-376. [CrossRef]

19. Heredia, A.C.; Oliva, M.I.; Zandalazini, C.I.; Agú, U.A.; Eimer, G.A.; Casuscelli, S.G.; Herrero, E.R.; Pérez, C.F.; Crivello, M.E. Synthesis, Characterization, and Catalytic Behavior of Mg-Al-Zn-Fe Mixed Oxides from Precursors Layered Double Hydroxide. Ind. Eng. Chem. Res. 2011, 50, 6695-6703. [CrossRef]

20. Heredia, A.C.; Oliva, M.I.; Agú, U.; Zandalazini, C.I.; Marchetti, S.G.; Herrero, E.R.; Crivello, M.E. Synthesis, characterization and magnetic behavior of Mg-Fe-Al mixed oxides based on layered double hydroxide. J. Magn. Magn. Mater. 2013, 342, 38-46. [CrossRef]

21. Foruzin, L.J.; Rezvani, Z. Ultrasonication construction of the nano-petal NiCoFe-layered double hydroxide: An excellent water oxidation electrocatalyst. Ultrason. Sonochem. 2020, 64, 104919. [CrossRef]

22. Bao, J.; Wang, Z.; Xie, J.; Xu, L.; Lei, F.; Guan, M.; Zhao, Y.; Huang, Y.; Li, H. A ternary cobalt-molybdenum-vanadium layered double hydroxide nanosheet array as an efficient bifunctional electrocatalyst for overall water splitting. Chem. Commun. 2019, 55, 3521-3524. [CrossRef]

23. Das, N.; Das, R. Synthesis, characterization and activation of quaternary layered double hydroxides for the one-pot synthesis of methyl isobutyl ketone. React. Kinet. Mech. Catal. 2010, 99, 397. [CrossRef]

24. Harizi, I.; Chebli, D.; Bouguettoucha, A.; Rohani, S.; Amrane, A. A New Mg-Al-Cu-Fe-LDH Composite to Enhance the Adsorption of Acid Red 66 Dye: Characterization, Kinetics and Isotherm Analysis. Arab. J. Sci. Eng. 2019, 44, 5245-5261. [CrossRef]

25. Song, F.; Hu, X. Ultrathin Cobalt-Manganese Layered Double Hydroxide Is an Efficient Oxygen Evolution Catalyst. J. Am. Chem. Soc. 2014, 136, 16481-16484. [CrossRef]

26. Oh, J.-M.; Park, M.; Kim, S.-T.; Jung, J.-Y.; Kang, Y.-G.; Choy, J.-H. Efficient delivery of anticancer drug MTX through MTX-LDH nanohybrid system. J. Phys. Chem. Solids 2006, 67, 1024-1027. [CrossRef]

27. Li, C.; Wei, M.; Evans, D.G.; Duan, X. Layered Double Hydroxide-based Nanomaterials as Highly Efficient Catalysts and Adsorbents. Small 2014, 10, 4469-4486. [CrossRef] [PubMed]

28. Choudhary, V.R.; Jha, R.; Jana, P. Solvent-free selective oxidation of benzyl alcohol by molecular oxygen over uranium oxide supported nano-gold catalyst for the production of chlorine-free benzaldehyde. Green Chem. 2007, 9, 267-272. [CrossRef]

29. Choi, G.; Kim, T.-H.; Oh, J.-M.; Choy, J.-H. Emerging nanomaterials with advanced drug delivery functions; focused on methotrexate delivery. Coord. Chem. Rev. 2018, 359, 32-51. [CrossRef]

30. Wang, S.L.; Hseu, R.J.; Chang, R.R.; Chiang, P.N.; Chen, J.H.; Tzou, Y.M. Adsorption and thermal desorption of Cr(VI) on Li/Al layered double hydroxide. Colloids Surf. A Physicochem. Eng. Asp. 2006, 277, 8-14. [CrossRef]

31. Chen, D.; Li, Y.; Zhang, J.; Li, W.; Zhou, J.; Shao, L.; Qian, G. Efficient removal of dyes by a novel magnetic $\mathrm{Fe}_{3} \mathrm{O}_{4} / \mathrm{ZnCr}$-layered double hydroxide adsorbent from heavy metal wastewater. J. Hazard. Mater. 2012, 243, 152-160. [CrossRef]

32. Ryu, S.-J.; Jung, H.; Oh, J.-M.; Lee, J.-K.; Choy, J.-H. Layered double hydroxide as novel antibacterial drug delivery system. J. Phys. Chem. Solids 2010, 71, 685-688. [CrossRef]

33. Stepanova, L.N.; Belskaya, O.B.; Vasilevich, A.V.; Leont'eva, N.N.; Baklanova, O.N.; Likholobov, V.A. Effect of the Composition of Initial Components and the Conditions of Activation on the Mechanochemical Synthesis of Magnesium-Aluminum Layered Double Hydroxides. Kinet. Catal. 2018, 59, 521-531. [CrossRef]

34. Seiyama, T.; Yamazoe, N.; Eguchi, K. Characterization and activity of some mixed metal oxide catalysts. Ind. Eng. Chem. Prod. Res. Dev. 1985, 24, 19-27. [CrossRef]

35. Védrine, J.C. Heterogeneous catalysis on metal oxides. Catalysts 2017, 7, 341. [CrossRef]

36. Velu, S.; Suzuki, K.; Gopinath, C.S. Photoemission and in Situ XRD Investigations on CuCoZnAl-Mixed Metal Oxide Catalysts for the Oxidative Steam Reforming of Methanol. J. Phys. Chem. B 2002, 106, 12737-12746. [CrossRef]

37. Cho, S.; Jang, J.-W.; Kong, K.-J.; Kim, E.S.; Lee, K.-H.; Lee, J.S. Anion-Doped Mixed Metal Oxide Nanostructures Derived from Layered Double Hydroxide as Visible Light Photocatalysts. Adv. Funct. Mater. 2013, 23, 2348-2356. [CrossRef]

38. Hu, W.; Wei, H.; She, Y.; Tang, X.; Zhou, M.; Zang, Z.; Du, J.; Gao, C.; Guo, Y.; Bao, D. Flower-like nickel-zinc-cobalt mixed metal oxide nanowire arrays for electrochemical capacitor applications. J. Alloys Compd. 2017, 708, 146-153. [CrossRef] 
39. Miura, N.; Lu, G.; Yamazoe, N. High-temperature potentiometric/amperometric $\mathrm{NO}_{\mathrm{x}}$ sensors combining stabilized zirconia with mixed-metal oxide electrode. Sens. Actuators B Chem. 1998, 52, 169-178. [CrossRef]

40. Paul, D.; Neogi, S. Synthesis, characterization and a comparative antibacterial study of $\mathrm{CuO}, \mathrm{NiO}$ and $\mathrm{CuO}-\mathrm{NiO}$ mixed metal oxide. Mater. Res. Express 2019, 6, 055004. [CrossRef]

41. Wang, Y.; Zhang, D.; Lv, D.; Sun, Y. Mg-Al mixed metal oxide film derived from layered double hydroxide precursor film: Fabrication and antibacterial properties. J. Taiwan Inst. Chem. Eng. 2015, 57, 160-166. [CrossRef]

42. Polychronopoulou, K.; Fierro, J.L.G.; Efstathiou, A.M. Novel Zn-Ti-based mixed metal oxides for low-temperature adsorption of $\mathrm{H}_{2} \mathrm{~S}$ from industrial gas streams. Appl. Catal. B Environ. 2005, 57, 125-137. [CrossRef]

43. Zhang, Z.-Q.; Liao, M.-C.; Zeng, H.-Y.; Xu, S.; Liu, X.-J.; Du, J.-Z.; Zhu, P.-H.; Huang, Q.-J. Temperature effect on chromium(VI) removal by $\mathrm{Mg} / \mathrm{Al}$ mixed metal oxides as adsorbents. Appl. Clay Sci. 2014, 102, 246-253. [CrossRef]

44. Ni, Z.-M.; Xia, S.-J.; Wang, L.-G.; Xing, F.-F.; Pan, G.-X. Treatment of methyl orange by calcined layered double hydroxides in aqueous solution: Adsorption property and kinetic studies. J. Colloid Interface Sci. 2007, 316, 284-291. [CrossRef] [PubMed]

45. Jiang, D.; Su, L.; Ma, L.; Yao, N.; Xu, X.; Tang, H.; Li, X. Cu-Zn-Al mixed metal oxides derived from hydroxycarbonate precursors for $\mathrm{H}_{2} \mathrm{~S}$ removal at low temperature. Appl. Surf. Sci. 2010, 256, 3216-3223. [CrossRef]

46. Mochane, M.J.; Magagula, S.I.; Sefadi, J.S.; Sadiku, E.R.; Mokhena, T.C. Morphology, Thermal Stability, and Flammability Properties of Polymer-Layered Double Hydroxide (LDH) Nanocomposites: A Review. Crystals 2020, 10, 612. [CrossRef]

47. Li, B.; Zhang, Y.; Zhou, X.; Liu, Z.; Liu, Q.; Li, X. Different dye removal mechanisms between monodispersed and uniform hexagonal thin plate-like $\mathrm{MgAl}-\mathrm{CO}_{3}{ }^{2-}-\mathrm{LDH}$ and its calcined product in efficient removal of Congo red from water. J. Alloys Compd. 2016, 673, 265-271. [CrossRef]

48. Jung, S.-Y.; Kim, B.-K.; Kim, H.-J.; Oh, J.-M. Development of Mesopore Structure of Mixed Metal Oxide through AlbuminTemplated Coprecipitation and Reconstruction of Layered Double Hydroxide. Nanomaterials 2021, 11, 620. [CrossRef]

49. INNOPOLIS Foundation. Advanced Ceramic Market: Technology Global Market Trend Report; INNOPOLIS Foundation: Daejeon, Korea, 2018; p. 4.

50. Gawande, M.B.; Pandey, R.K.; Jayaram, R.V. Role of mixed metal oxides in catalysis science-Versatile applications in organic synthesis. Catal. Sci. Technol. 2012, 2, 1113-1125. [CrossRef]

51. Dzene, L.; Jeguirim, M.; Brendlé, J.; Limousy, L. Second international symposium Clays and ceramics for environmental applications. C. R. Chim. 2019, 22, 103-104. [CrossRef]

52. Ministry of SMS and Startups. Technology Roadmap for SME 2018-2020; Ministry of SMS and Startups: Daejeon, Korea, 2018; pp. 19-21.

53. Arora, A.K.; Jaswal, V.S.; Singh, K.; Singh, R. Applications of metal/mixed metal oxides as photocatalyst: (A review). Orient. J. Chem. 2016, 32, 2035. [CrossRef]

54. Kim, B.-K.; Gwak, G.-H.; Okada, T.; Oh, J.-M. Effect of particle size and local disorder on specific surface area of layered double hydroxides upon calcination-reconstruction. J. Solid State Chem. 2018, 263, 60-64. [CrossRef]

55. Millange, F.; Walton, R.I.; O'Hare, D. Time-resolved in situ X-ray diffraction study of the liquid-phase reconstruction of Mg-Alcarbonate hydrotalcite-like compounds. J. Mater. Chem. 2000, 10, 1713-1720. [CrossRef]

56. Li, D.; Lu, M.; Cai, Y.; Cao, Y.; Zhan, Y.; Jiang, L. Synthesis of high surface area $\mathrm{MgAl}_{2} \mathrm{O}_{4}$ spinel as catalyst support via layered double hydroxides-containing precursor. Appl. Clay Sci. 2016, 132-133, 243-250. [CrossRef]

57. Sun, G.; Sun, L.; Wen, H.; Jia, Z.; Huang, K.; Hu, C. From Layered Double Hydroxide to Spinel Nanostructures: Facile Synthesis and Characterization of Nanoplatelets and Nanorods. J. Phys. Chem. B 2006, 110, 13375-13380. [CrossRef] [PubMed]

58. Jung, S.-Y.; Kim, B.-K.; Hirata, S.; Inada, M.; Oh, J.-M. Particle size effect of layered double hydroxide on the porosity of calcined metal oxide. Appl. Clay Sci. 2020, 195, 105701. [CrossRef]

59. Yan, Z.; Zhu, B.; Yu, J.; Xu, Z. Effect of calcination on adsorption performance of Mg-Al layered double hydroxide prepared by a water-in-oil microemulsion method. RSC Adv. 2016, 6, 50128-50137. [CrossRef]

60. Chen, C.; Yang, M.; Wang, Q.; Buffet, J.-C.; O’Hare, D. Synthesis and characterisation of aqueous miscible organic-layered double hydroxides. J. Mater. Chem. A 2014, 2, 15102-15110. [CrossRef]

61. Zhu, X.; Chen, C.; Suo, H.; Wang, Q.; Shi, Y.; O'Hare, D.; Cai, N. Synthesis of elevated temperature $\mathrm{CO}_{2}$ adsorbents from aqueous miscible organic-layered double hydroxides. Energy 2019, 167, 960-969. [CrossRef]

62. Putra, A.T.S.P. An improved method for high photocatalytic performance of $\mathrm{ZnAl}_{2} \mathrm{O}_{4}$ spinel derived from layered double hydroxide precursor. SN Appl. Sci. 2020, 2, 842. [CrossRef]

63. Szabados, M.; Kónya, Z.; Kukovecz, Á.; Sipos, P.; Pálinkó, I. Ultrasonically-assisted mechanochemical synthesis of zinc aluminate spinel from aluminium-rich layered double hydroxide. J. Solid State Chem. 2019, 272, 227-233. [CrossRef]

64. Magri, V.R.; Duarte, A.; Perotti, G.F.; Constantino, V.R. Investigation of Thermal Behavior of Layered Double Hydroxides Intercalated with Carboxymethylcellulose Aiming Bio-Carbon Based Nanocomposites. ChemEngineering 2019, 3, 55. [CrossRef]

65. Castro, R.H.R.; Tôrres, R.B.; Pereira, G.J.; Gouvêa, D. Interface Energy Measurement of MgO and ZnO: Understanding the Thermodynamic Stability of Nanoparticles. Chem. Mater. 2010, 22, 2502-2509. [CrossRef]

66. Gidado, S.M.; Akanyeti, İ. Comparison of Remazol Brilliant Blue Reactive Adsorption on Pristine and Calcined ZnAl, MgAl, ZnMgAl Layered Double Hydroxides. Water Air Soil Pollut. 2020, 231, 146. [CrossRef]

67. Huang, J.; Yang, Z.; Wang, R.; Zhang, Z.; Feng, Z.; Xie, X. Zn-Al layered double oxides as high-performance anode materials for zinc-based secondary battery. J. Mater. Chem. A 2015, 3, 7429-7436. [CrossRef] 
68. Zhang, L.; Liu, J.; Xiao, H.; Liu, D.; Qin, Y.; Wu, H.; Li, H.; Du, N.; Hou, W. Preparation and properties of mixed metal oxides based layered double hydroxide as anode materials for dye-sensitized solar cell. Chem. Eng. J. 2014, 250, 1-5. [CrossRef]

69. Starukh, H.; Levytska, S. The simultaneous anionic and cationic dyes removal with ZnAl layered double hydroxides. Appl. Clay Sci. 2019, 180, 105183. [CrossRef]

70. Huang, G.; Sun, Y.; Zhao, C.; Zhao, Y.; Song, Z.; Chen, J.; Ma, S.; Du, J.; Yin, Z. Water-n-BuOH solvothermal synthesis of $\mathrm{ZnAl}-\mathrm{LDH}$ with different morphologies and its calcined product in efficient dyes removal. J. Colloid Interface Sci. 2017, 494, 215-222. [CrossRef]

71. Das, J.; Patra, B.S.; Baliarsingh, N.; Parida, K.M. Calcined Mg-Fe-CO $\mathrm{CO}_{3} \mathrm{LDH}$ as an adsorbent for the removal of selenite. J. Colloid Interface Sci. 2007, 316, 216-223. [CrossRef]

72. Türk, T.; Alp, İ; Deveci, H. Adsorption of As(V) from water using Mg-Fe-based hydrotalcite (FeHT). J. Hazard. Mater. 2009, 171, 665-670. [CrossRef]

73. Yang, Y.; Gao, N.; Deng, Y.; Zhou, S. Adsorption of perchlorate from water using calcined iron-based layered double hydroxides. Appl. Clay Sci. 2012, 65-66, 80-86. [CrossRef]

74. Peng, C.; Dai, J.; Yu, J.; Yin, J. Calcined Mg-Fe layered double hydroxide as an absorber for the removal of methyl orange. AIP Adv. 2015, 5, 057138. [CrossRef]

75. Xu, Y.; Liu, T.; Huang, Y.; Zhu, J.; Zhu, R. Role of phosphate concentration in control for phosphate removal and recovery by layered double hydroxides. Environ. Sci. Pollut. Res. 2020, 27, 16612-16623. [CrossRef]

76. Zhang, Z.; Xu, S.; Zeng, H.; Liao, M.; Du, J.; Duan, H. Influence of Calcination Temperature on the Microstructure and Catalytic Performance of Mg/Al Hydrotalcites Catalysts for Alcoholysis of Propylene Oxide. J. Nanosci. Nanotechnol. 2016, 16, 12677-12683. [CrossRef]

77. Lonkar, S.P.; Kutlu, B.; Leuteritz, A.; Heinrich, G. Nanohybrids of phenolic antioxidant intercalated into MgAl-layered double hydroxide clay. Appl. Clay Sci. 2013, 71, 8-14. [CrossRef]

78. Ray, S.; Joy, M.; Sa, B.; Ghosh, S.; Chakraborty, J. pH dependent chemical stability and release of methotrexate from a novel nanoceramic carrier. RSC Adv. 2015, 5, 39482-39494. [CrossRef]

79. Chakraborty, M.; Dasgupta, S.; Soundrapandian, C.; Chakraborty, J.; Ghosh, S.; Mitra, M.K.; Basu, D. Methotrexate intercalated ZnAl-layered double hydroxide. J. Solid State Chem. 2011, 184, 2439-2445. [CrossRef]

80. Starukh, G. Photocatalytically Enhanced Cationic Dye Removal with Zn-Al Layered Double Hydroxides. Nanoscale Res. Lett. 2017, 12, 391. [CrossRef]

81. Zhang, Y.; Li, X. Preparation of Zn-Al CLDH to Remove Bromate from Drinking Water. J. Environ. Eng. 2014, $140,04014018$. [CrossRef]

82. Miessler, G.L.; Fischer, P.J.; Tarr, D.A. Inorganic Chemistry; Pearson: London, UK, 2014.

83. Han, Y.-J.; Kim, J.M.; Stucky, G.D. Preparation of Noble Metal Nanowires Using Hexagonal Mesoporous Silica SBA-15. Chem. Mater. 2000, 12, 2068-2069. [CrossRef]

84. Bui, T.X.; Choi, H. Adsorptive removal of selected pharmaceuticals by mesoporous silica SBA-15. J. Hazard. Mater. 2009, 168, 602-608. [CrossRef]

85. Mesa, M.; Sierra, L.; Patarin, J.; Guth, J.-L. Morphology and porosity characteristics control of SBA-16 mesoporous silica. Effect of the triblock surfactant Pluronic F127 degradation during the synthesis. Solid State Sci. 2005, 7, 990-997. [CrossRef]

86. Hwang, Y.K.; Chang, J.-S.; Kwon, Y.-U.; Park, S.-E. Microwave synthesis of cubic mesoporous silica SBA-16. Microporous Mesoporous Mater. 2004, 68, 21-27. [CrossRef]

87. Wang, J.; Zhou, J.; Li, Z.; He, Y.; Lin, S.; Liu, Q.; Zhang, M.; Jiang, Z. Mesoporous mixed metal oxides derived from P123-templated Mg-Al layered double hydroxides. J. Solid State Chem. 2010, 183, 2511-2515. [CrossRef]

88. Pahalagedara, M.N.; Pahalagedara, L.R.; Kuo, C.-H.; Dharmarathna, S.; Suib, S.L. Ordered Mesoporous Mixed Metal Oxides: Remarkable Effect of Pore Size on Catalytic Activity. Langmuir 2014, 30, 8228-8237. [CrossRef] [PubMed]

89. Oka, Y.; Kuroda, Y.; Matsuno, T.; Kamata, K.; Wada, H.; Shimojima, A.; Kuroda, K. Preparation of Mesoporous Basic Oxides through Assembly of Monodispersed Mg-Al Layered Double Hydroxide Nanoparticles. Chem. A Eur. J. 2017, 23, 9362-9368. [CrossRef]

90. Xie, J.; Yamaguchi, T.; Oh, J.-M. Synthesis of a mesoporous Mg-Al-mixed metal oxide with P123 template for effective removal of Congo red via aggregation-driven adsorption. J. Solid State Chem. 2021, 293, 121758. [CrossRef]

91. Li, X.; Xiao, W.; He, G.; Zheng, W.; Yu, N.; Tan, M. Pore size and surface area control of MgO nanostructures using a surfactanttemplated hydrothermal process: High adsorption capability to azo dyes. Colloids Surf. A Physicochem. Eng. Asp. 2012, $408,79-86$. [CrossRef]

92. Rani, K.M.; Palanisamy, P.N. Synthesis and Characterization of Mesoporous, Nanostructured Zinc Aluminium Carbonate Layered Double Hydroxides (ZAC-LDHs) and Its Calcined Product (CZA-LDH). J. Inorg. Organomet. Polym. Mater. 2018, 28, $1127-1135$. [CrossRef]

93. Zhao, L.; Xu, T.; Lei, X.; Xu, S.; Zhang, F. Scalable preparation of alginate templated-layered double hydroxide mesoporous composites with enhanced surface areas and surface acidities. J. Nanosci. Nanotechnol. 2011, 11, 3291-3297. [CrossRef]

94. Duan, S.-C.; Meng, Z.-Z.; Xie, J.; Chen, C.-X. Preparation and Catalytic Property of ZnAlCe Ternary Complex Oxide Porous Materials Based on Rape Pollen Biotemplates. J. Inorg. Mater. 2015, 4, 420-426. [CrossRef] 
95. Wang, D.; Li, S.; Du, Y.; Wu, X.; Chen, Y. Self-Templating Synthesis of 3D Hierarchical $\mathrm{NiCo}_{2} \mathrm{O}_{4} @$ NiO Nanocage from Hydrotalcites for Toluene Oxidation. Catalysts 2019, 9, 352. [CrossRef]

96. Xiang, X.; Hima, H.I.; Wang, H.; Li, F. Facile Synthesis and Catalytic Properties of Nickel-Based Mixed-Metal Oxides with Mesopore Networks from a Novel Hybrid Composite Precursor. Chem. Mater. 2008, 20, 1173-1182. [CrossRef]

97. Feng, R.; Al-Megren, H.A.; Zhang, Z.; Al-Kinany, M.C.; Yan, Z.; Zhang, Z.; Gao, X. Soft-templating pathway to create nanostructured $\mathrm{Mg}-\mathrm{Al}$ spinel as high-temperature absorbent for $\mathrm{SO}_{2}$. J. Porous Mater. 2014, 21, 947-956. [CrossRef] 